\title{
Sakarya Osmanlı Mezar Taşlarından Örneklerle Dardağan Serpuşlar
}

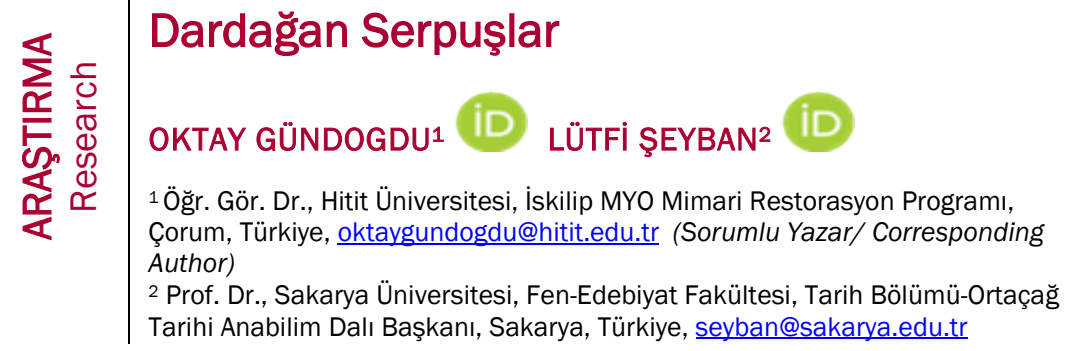

Geliş Tarihi / Received Date : 15.10 .2021

Kabul Tarihi / Accepted Date : 07.12.2021

Yayın Tarihi / Published Date : 31.12.2021

\section{Atif/ Cite as}

Gündoğdu, Oktay - Şeyban, Lütfi. "Sakarya Osmanlı Mezar Taşlarından Örneklerle Dardağan Serpuşlar”. İstem, 19/38 (2021): 273-302. https://doi.org/10.31591/istem.1036095

\section{Öz}

Türk tarihinde yüzyılların kazanımlarını hakka teslimiyet anlayışıyla bir hakkâkın elinde bedene büründürmek olarak görülebilecek mezar taşları, Türk kültürünün sürdürülmesini sağlayacak edebi detaylar yanında kültürel değerleri de bünyesinde barındıran yerel kaynakların başında gelmektedir. Bu çalışmada, Sakarya ilinin tamamında yapılan saha çalışması sonucunda elde edilen verilerin, türlerine göre sınıflandırılarak mezar taşı literatürüne kazandırılması; fakat özellikle, tespit edilen 1210 adet mezar taşı içinden, kimlik ve kıyafet verileri babında "Dardağan" serpûşlu şâhidelerin sanat tarihi yöntemine uygun şekilde değerlendirilmesi amaçlanmıştır. Bunlar arasında yeniçeri mezar taşları, yeterli miktardaki verilerin konuyu örneklemede kullanıması sayesinde, makalede önemli bir yer tutmaktadır. Yeniçeri mezar taşı özelliklerini barındıran örnekleri Sakarya sınırları içerisinde tespit etmiş olmak, 1826 yılında lağvedilmiş olan bir askeri sınıfın yayıım ağını, nüfuzunu ve sayılarını göstermesi bakımından Türkiye'deki çaıışmalar için önemli kazanım olabilir. Çalışmada, tespit edilen dardağan serpûşlu mezar taşları, etimolojik değerlendirmeden ziyade, kitâbeleri üzerinden tasnif ve tahlile tâbi kılınmıştır. Dardağan serpûş ve türevleri bir bütün halinde ele alındığında, mezar taşı kitâbelerinde kayıtlı mesleki sınıflara dair yapılan ayrımın, serpûş tiplerini net olarak ortaya çıkardığı görülecektir. $\mathrm{Bu}$ yöntemle elde edilen veriler, dardağan serpûşlar için genel bir değerlendirme yapmayı mümkün kılmıştır. Bunun yanısıra Sakarya Sapanca'da, 1812 tarihli 3 adet yeniçeri mezar taşı, remizlerine istinaden; 5 adet mezar taşı ise bölüklerine istinaden tespit edilerek ilk kez bu çalışma sayesinde literatüre kazandırılmış olacaktır.

Anahtar Kelimeler: Sakarya, Yeniçeri, Mezar Taşı, Beşe, Serdengeçti, Dardağan.

\section{Abstract}

Dardagan Serpuşes with Examples from Sakarya Ottoman Gravestones

In this study, where Turkish art will be explained with identity and clothing, it will be tried to ex-




plain the witnesses titled "Dardağan" and their characteristics among 1210 tombstones found in the provincial borders of Sakarya. The data obtained as a result of the field work carried out in all Sakarya districts will be classified according to their types and added to the gravestone literature. Among them, we considered it appropriate to collect the gravestones of members of the Janissary military class in a single article due to sufficient data. Identifying the characteristics of janissary tombstones in the borders of Sakarya is a gain for the literature in terms of showing the distribution network, influence and numbers of a military class that was abolished in 1826. The main purpose of this study is not an etymological evaluation, but a classification study on the inscriptions of the identified works on dardağan titles. When Dardağan title and its derivatives are considered as a whole, making a distinction about occupational groups will reveal the types of titles clearly, as stated in their inscriptions. In addition to these, 3 janissary stones dated 1812 in Sakarya Sapanca were emphasized with their symbol and they were brought to the literature for the first time in this study.

Keywords: Sakarya, Janissary, Tombstone, Beshe, Serdengechty, Dardaghan.

\section{Giriş}

Sanatsal bir tasarımın tasvir ya da heykel biçiminde esere dönüşmüş olan ifadesi, tezyin ve âhengin ötesinde hem sanatkârın hem de eserin temsil ettiği kültürün izlerini de taşımaktadır. Osmanlı devletinde kişilerin toplumsal statü simgesi olarak kullandıkları serpûşlar, ölümünden sonra bu kez kabir şâhidesinin başlığı olmaktaydı. Dolayısıyla şâhide serpûşları, Türk kültürünün aktarılması ve toplumsal statü bilincinin kıyafete yansıtılmasında önemli bir gösterge sayılmalıdır. Bu serpûşlar aynı zamanda toplumsal zümrelere işaret eden örnekler olarak da görülebilir.

Şâhidelerdeki tezyinat ve tasarım unsurları, gerçekte asırlardır süregelen bir kültürel birikimi yansıtmaktadırlar. Yapılan araştırmalar gösteriyor ki; kültürün yaratıcıları ve taşıyıcıları, tüm farkındalıkları örgelere nakşederek geriye bilinçli izler bırakmışlardır. Osmanlı mezar kültüründe, bu izlere uymayan veya kabul görmeyen bir simgeyi yaşatmak mümkün olmazdı. Hem imparatorluk nezdinde hem de halk kültüründe yaşamak ancak çoğulcu kabullerin bir sıfatı olmakla açıklanabilir. Bu tür tasarımlar bir beğeni olmanın ötesinde birer temsildirler. Mezar taşları, öz kültürü taşıyan milli belleğin besleyici unsurlarından birisidir. ${ }^{1}$ Üstlendikleri sıfatlar cihetinden bakıldığında, malzemenin bir ifade aracı olarak kullanılması, anlamlar yüklenmesi, toplumsal karşılığının olması ve üç boyutlu olması mezar taşlarını heykel sınıfına sokmaktadır. ${ }^{2}$ Fazıl İsmail Ayanoğlu'nun ifadesiyle; hiçe sayılan bu makberler, bize tarihimizi, edebiyatımızı, dilimizi, sanatımızı verecek müstesna bir alandır. ${ }^{3}$

Serpûş kavramı, milletlerin özniteliklerini yansıtan bir unsur ve çağları yaşatan bir ölçü olarak tasvir edilmiştir. Hatta kozmopolit yerleşimlerde ulusun temsili sayılmıştır. Farklı tipleri bulunan "serpûş, börk, kalpak, papah, külah, kavuk, sarık, amâme" isimleri başlık kavramını ifade etmektedir. ${ }^{4}$

\footnotetext{
${ }^{1}$ Beyhan Karamağaralı, Türk Mimari Eserlerinde Ahlat Mezar Taşları, (Ankara: Elektronik Illetişim Ajansı Yayınları, 1993), 1.

2 Mehmet Haseki, "Plastik Açıdan Türk Mezar Taşları", İstanbul Devlet Güzel Sanatlar Akademisi (1976):13-14.; Arzu Çakıl Atıl, "Rölyef Heykel” Yedi: Sanat, Tasarım ve Bilim Dergisi 14 (2015): 110.

3 Fazıl İsmail Ayanoğlu, “Vakıflar İdaresince Tamir Ettirilen Tarihi Makberler”, Vakıflar Dergisi 2 (1942): 399.

${ }^{4}$ Ahmet Caferoğlu, "Türk Onomastiğinde "Serpûş" yahut "Serpuş", VIII: Türk Dil Kurultayında Okunan Bilimsel Bildiriler, (Ankara: TTK Yayınları, 1960): 116.
} 
Serpûşlar üzerine yapılan incelemeler dikkate alındığında karmaşık bir tanımlama ile karşılaşılmaktadır. Serpûş türlerinin sosyal tabanlı olması ve birçoğunun temsil taşıması değişimi ve kabulü etkilemiş olmalıdır. Nitekim Osmanlı mezar taşlarının oluşumunun temelinde dini kabullerin olduğu bilinmektedir. Hz. Muhammed tarafından sarığın kullanılması ve Müslüman toplumların sünnete bağ|lığı düşünüldüğünde tercih edilme yoğunluğu daha iyi anlaşılacaktır. ${ }^{5}$

Osmanlı mezar taşlarında serpûş türleri, araştırmacılar tarafından tiplerine göre tasnif edilmiştir. Bunlar arasında sayıları ve tipleri nedeniyle en çok tartışılan serpûş, yeniçeri mezar taşları olmuştur. 1935 yılından bugüne kadar akademik çalışmalar ilerledikçe, birikim ve örneklerin artmasıyla veriler gelişmiştir. Serpûşlarda tipolojik tasniflerin derli toplu yapıldığı ilk çalışma, 2006 tarihinde H. Necdet İşli'nin eseridir. ${ }^{6} 2009$ yılında Edhem Eldem, bu süreci kronolojik olarak vermek suretiyle, yeniçeri mezar taşlarının sayıları, börk dışında başka serpûş tiplerinin kullanılması, II. Mahmud döneminde (1808-1839) bu taşların devlet veya şahıs nezdinde kırdırııı kırdırılmadığına dair düşünceleri kaynaklar üzerinden aktarmıştır. ${ }^{7} 2015$ yılında Halit Çal, dardağan serpûşları "Sarıklı" gruplar içerisinde değerlendirmeye alarak bugüne kadar gelen tartışmaları dipnot bölümünde araştırmacılara sunmuştur. ${ }^{8} 2017$ yılında H. Necdet isşli ile Mehmet Kökrek; remizler üzerinden hareketle sistemli bir çalışma yaparak örnekleri aktarmışlardır. ${ }^{9} 2018$ yılında Halit Çal; Karadeniz bölgesindeki dağıııma dikkat çektiği çalışmasında, oranları belirterek değerlendirmede bulunmuştur. ${ }^{10}$

Bu çalışmalar üzerine bizim yaptığımız ilave katkı ise, Sakarya Osmanlı mezar taşlarındaki kitâbe verilerinin tasnif edilerek değerlendirilmesi olmuştur. Kitâbesinde meslek grubu ya da unvanları belirtilenler ile belirtilmeyenlerin aylrımının yapılmasının ardından, net veriler üzerinden tasnif yapmak mümkün olmuştur. Sonuçta bu tür tasnifler sayesinde, ülke genelinde yeniçeri mezar taşları, kitâbelerindeki kimlik bilgileriyle ele alınmış olmaktadır. Aksi halde serpûş aynı görünmekle birlikte Yeniçeri sınıfına mensubiyetini kesin olarak belirlemek zorlaşacaktır. Özellikle kitâbe kaydında yeniçeri sınıflarından olduğu belirtilen fakat serpûş tipleri yeniçerilerinkinden farklı olan şâhidelerin bulunması, bu yöntemin yapılmasını gerekli kılmaktadır.

\section{Dardağan Serpûşların Tanımı ve Nitelikleri}

Mezar taşlarının en üstte bulunan kısmı serpûş, başlık, sikke, börk, kalpak, papah, külah, kavuk, sarık, amâme gibi adlarla anılmaktadır. Serpûşa sarılan ince uzun tülbent veya şaldan ibaret kumaşa ise sarık denir. Başlığın türleri ve

\footnotetext{
5 İsmail Yalçın, “Sarık”, TDV İslâm Ansiklopedisi 36 (İstanbul: TDV Yayınları, 2009): 154; Nebi Bozkurt, “Sarık”, TDV İslâm Ansiklopedisi 36 (İstanbul: TDV Yayınları, 2009): 152.

${ }^{6}$ H. Necdet İşli. Yeniçeri Mezartaşları. (İstanbul: Turkuaz Yayınları, 2006).

7 Edhem Eldem, "Yeniçeri Mezartaşları Kitabı Vesilesiyle Yeniçeri Taşları ve Tarih Üzerine", Toplumsal Tarih Dergisi 188 (2009):10.

8 Halit Çal, Boyabat Mezar Taşları, (Ankara: Boyabat Belediyesi Kültür Yayınları, 2015), 131-132.

9 H. Necdet İşli ve Mehmet Kökrek, Yeniçeriler Remizleri ve Mezar Taşları, (İstanbul: Dergâh Yayınları, 2017), 86.

10 Halit Çal, "Karadeniz Bölgesinde 18. Yüzyıl Erkek Mezar Taşları”, Türk Kültürü ve Hacı Bektaş Veli Araştırma Dergisi 87 (2018): 115,118,121.
} 
tipleri farklı olabilmektedir. Yeniçeri serpûşlarından birisi olarak kabul edilen "dardağan" serpûş, bir keçe veya külah çevresinin geniş veya dar olarak, sıkça sarılmasıyla oluşturulmuş olup hacimli bir görünüşe sahiptir. ${ }^{11}$

Yeniçeriler, dardağan serpûşları baş tacı olarak kullanmış ve sarıkları farklı şekillerde sarmışlardır ${ }^{12}$. Başka deyişle, Yeniçerilerin düzenli ve ince sarılmış destarlarla oluşturdukları serpuşlarıdır. Sarıkların yoğun tutulma amacı ise bu başlığı kullanan askerin kendi kefenini kendi başında taşıma düşüncesiyle ilgili olup, baş tacı olarak adlandırılması da bu düşünceden kaynaklanmaktadır. ${ }^{13}$ Ayrıca dardağan serpûşlar için, 1698-1862 yılları arasında "yeniçeri şâhidelerinde görülen tip" şeklinde bir tanımlama da yapılmıştır. ${ }^{14}$ Başlığın büyüklüğü nedeniyle Osmanlı döneminde hemen alınabilecek ucuzlukta bir ürün değildir. Nitekim kayıtlardan bilindiği kadarıyla büyük serpûşlar pahalı iken küçükleri ucuz oluyordu. ${ }^{15}$

Bir keçe üzerine sarılan ve kefenle özdeşleştirilen bu serpûşlar, ölümle hayatın aynı bedendeki temsili veya dünya ve âhiret bütünlemesi olarak yorumlanabilir. Serpûşların dağınık, geniş ve yüksek olması ise bir yeniçeri alameti olmalıdır. Yeniçeri mezar taşları denildiğinde genellikle börklü başlığı olan mezar taşları akla gelmektedir. Fakat yeniçeri mezarlarının serpûşlarında çok değişik tipler de görülmektedir. Bunlar arasında "dardağan, serdengeçti, börk, kalafat ve kuka" en çok tercih edilenler arasında yer alır. ${ }^{16}$ Yeniçeri serpûşlarındaki bu çeşitlenme, bazı araştırmacılar tarafından temelde "dardağan" ve "börk" olmak üzere iki ana sınıfta zikredilmiştir. ${ }^{17}$

Yeniçeri Ocağında dardağan, aynı zamanda "beşe" unvanlı çorbacı veya ağa olamamış kimseler tarafından kullanılan serpûş olarak da tanımlanmaktadır. ${ }^{18}$ Bunun yanı sıra, Sultan 4. Mehmed tarafından giyilen bu başlığın, padişah ve saray halkından kimseler tarafından da tercih edildiği ve tek sorguçlu renkli bir malzemeden mamul olduğu kayıtlarda geçmektedir. ${ }^{19}$

Bu değerlendirmeler sonucunda dardağan serpûşların gündelik mi yoksa

\footnotetext{
11 Bozkurt, "Sarık", 152-154; Mehmet Zeki Pakalın, Osmanlı Tarih Deyimleri ve Terimleri Sözlüğü 1 , (istanbul: MEB Yayınları, 1993), 393.

12 H. Necdet İșli. Yeniçeri Mezartașları. (İstanbul: Turkuaz Yayınları, 2006).

13 Mehmet Kökrek, “Osmanlı Serpuşları", ISMEK El Sanatları Dergisi 20 (2015): 50; H. Necdet İşli, Osmanlı Serpuş/arı, (İstanbul: 2010 istanbul Kültür Bașkenti Ajansı Yayınları, 2009), 120.

14 Halit Çal, "Türklerde Mezar - Mezar Taşları", Aile Yazıları 8, (2015): 311.; Halit Çal ve Filiz Canyurt, "Edirne Şehrindeki Mezar Tașlarında Serpûș Tipleri", TURKMES 2019 Tam Metin Bildiriler, (Kayseri: Kimlik Yayınları, 2020), 238.

15 Nevzat Erkan, “Osmanlı İstanbul'unda Cenaze ve Defin Isşlemleri: H.1117/M.1705 Tarihli Sicil Kaydına Göre", Rumeli İslâm Araștırmaları Dergisi 4, (2019): 58.

16 Kökrek, "Osmanlı Serpuşları", 49; İşli ve Kökrek, Yeniçeri Mezartaşları, 67.

17 Süleyman Berk, “Osmanlı Mezar Taşı Kitâbelerinde Serpûşlar ve Anlamları”, 1. Uluslararası Türkìslam Mezar Taşları Kongresi Bildiriler Kitabı, (Aydın: Yeni Fikir Dergisi Yayınları, 2018), 118.

18 İșli ve Kökrek, Yeniçeriler Remizleri ve Mezar Taşları, 86.

19 İzzet Kumbaracılar, Serpuşlar, (İstanbul: Türkiye Turing ve Otomobiller Kurumu Yayını, 1979), 9.; bu bilgi ve minyatürlerdeki tasvirlerden hareketle renkli olduklarını düșündüğümüz bu serpûșların lazer taramalarla incelendikten sonra netleşeceği ve mezar taşı literatürüne sağlıklı veriler olarak döneceğini düşünüyoruz. Aynı șekilde renkli süsleme uygulaması için sosyal statü belirteci olması ve vezirlerin paşaların serpûşlarının da renkli olarak yapıldığına işaret eden yayın için bknz.; Süleyman Berk, Zeytin Burnu'nun Tarihi Mezar Taşları - Zamanı Așan Tașlar, (İstanbul: Zeytin Burnu Belediyesi Yayınları, 2006), 31-32.
} 
törensel bir eşya mı olduğu düşüncesi sorgulanmaktadır. Bu yönde yapılan çaıışmalara bakıldığında, dardağan serpûşların perişan, dağınık bir düzende oluşturulmuş serpûşlar olarak tanımlandığı ${ }^{20}$ dikkat çeker ki, bu törensel bir düzenden oldukça uzak bir ifadedir. Buna ek olarak, Edhem Eldem, Charles White'ten aktardığı bilgiye istinaden, "adi kavuk" teriminin H.N. İşli'nin verileriyle karşılaştırıldığında "dardağan” ile uyuşma gösterdiğini düşünmektedir. Bu tür karşılaştırmaların yanısıra, minyatürlerde dardağan serpûş kullanımına da dikkat çekmek gerekmektedir. Çünkü minyatürler, her ne kadar sorgulamaya açık veriler sağlıyor olsa da, döneminin ürünü olması ve dardağan için tip uyumu örnekleri sergilemesi açııından önemlidir. Mesela Selimnâme'de gösterilen savaş sahnesinde, dardağan serpûş kullanan yeniçeriler at üzerinde, Surnâme-i Vehbî̀de ise börklü serpûşlar giyen yeniçeriler sünnet şenliğinin ziyafetinde tasvir edilmiştir. ${ }^{21}$ Burada bu verilerin değerlendirmesini yapabilmek için, öncelikle savaş sahnesinin törensel bir kıyafet düzeniyle tezyin edilip edilmediği bilgisine sahip olmamı gerekir ki, biz bu bilgiye henüz erişebilmiş değiliz.



Şekil 1. Selimnâme, Dardağan Serpûşlu Yeniçerileri Minyatürleri (TDV islâm Ansiklopedisi, 2013, 454-455).

Mesâlihu'I-Müslimîn'de uzunca bahsedilen önemli bir konu, yeniçeri serpûşlarının çok çeşitli olduğunu ortaya çıkarmaktadır. Yeniçeri ocak düzeninin bozulmuş olduğuna dikkat çeken çalışma, çok sayıda arşiv belgesinde yeniçerilerin asli görevlerinin dışında başka işler yaptığını (hamamcı, terzi, kasap), buna mani olmak amacıyla dışarıda fark edilmesinler diye farklı türde serpûş takmalarını sağlamıştır. ${ }^{22}$

Tasvir edilen serpûşta şeb-külâh üzerine çalma sarmalarından bahisle dardağan serpûş nitelendirmesinin yapıldığını H. N. İşli ve M. Kökrek değerlendirmişlerdir. ${ }^{23}$ Yine 18. yüzyılın sonlarında, İstanbul'da 1110 iş yerinin birçoğunun kayıtlarında, unvanları nedeniyle ilişkilendirilen yeniçeri ve ortalarının tica-

\footnotetext{
${ }^{20}$ Edhem Eldem, “Yeniçeri Mezartașları Kitabı Vesilesiyle Yeniçeri Tașları ve Tarih Üzerine”, 10-12.

21 Kemal Beydilli, "Yeniçeri”, TDV İslâm Ansiklopedisi 43, (İstanbul: TDV Yayınları, 2013): 450-462.

22 Yaşar Yücel, Osmanlı Devlet Teşkilatına Dair Kaynaklar, (Ankara: TTK Yayınları, 1988), 74.

23 İşli ve Kökrek. Yeniçeriler Remizleri ve Mezar Taşları, 86.
} 
retle meşguliyeti, vergiden muaf olmaları nedeniyle iktisadi sistemin bozulmasında etkili oldukları dikkatlerden kaçmamaktadır. Hatta bu oranın \%40 şeklinde belirtilmesi yeniçerilerin asli vazifesinden haylice uzaklaşmış ve esnaf düzenini de bozmuş olduğunun işaretidir. ${ }^{24}$ Yukarıdaki beyanı destekler mahiyetteki bu veriler, ticaretle uğraşan yeniçerilerin serpûşlarının da değişmiş olma intimalini artırmaktadır.

Son yıllarda yapılan mezar taşı çalışmaları incelendiğinde, dardağan serpûş için farklı tasvir, tipleme ve isimlendirmelere gidildiği görülmektedir. Bunlar arasında "burmalı sarıklı kavuk, sarıklı serpûş, kavuk, örfi kavuk, yuvarlak serpûşlu şerit sarıklı kavuk ${ }^{25}$, çapraz sarılmış sarık şeklinde bir serpûş ${ }^{26}$, dilimli sivri külah üzerine sarılmış dolamalı örfi kavuk-sivri külah üzerine destar dolamalı örfi kavuk-dolamalı örfi kavuk- basık dilimli dardağan kavuk ${ }^{27}$ " vb. sayılabilecek örneklerdendir. Sakarya şâhide kitâbelerinde, yeniçeri sınıflarından olduğu belirtilen fakat yukarıda belirtilenlerden farklı serpûş tipleri görülen şâhidelerin bulunması, burada yeni bir değerlendirmenin yapılmasını gerekli kılmaktadır. Dolayısıyla öncelikli yaklaşım kitâbî veriler üzerinden gitmektir. Bunları sınıflandırırken çalışma sahasında tespit edilen tüm mezar taşları ele alınarak tipolojiye gidilmiştir. Bir mezar taşının yeniçeri taşı sayılması için niteliklerin belirtildiği bir çalışma da M. Burak Çetintaş tarafından yapılmış olup burada, kitâbelerin en az dikkat çeken fakat önemli bir ibare olduğu belirtilmiştir. ${ }^{28}$ Kitâbe ve meslek gruplarılya verilen Sakarya'daki yeniçeri mezar taşları, yeniçerilerin kendi görevleri dışında farklı mesleklerde çalıştığını mezar taşlarında görmek bakımından ayrıca mühimdir.

N. İşli tarafından yapılan tanımlamalara göre, 1698 tarihinden itibaren görülen dardağan serpûşlar, farklı araştırmacılar tarafından form niteliklerini tasvir edici tip içerisinde sınıflandırımışlardır. Halit Çal bu türleri "sarıklı grup" adı altında türlere ayırarak; ${ }^{29}$ Laqueurr "E Tipi” şeklinde harflerle; ${ }^{30}$ N. İşli-M. Kökrek $^{31}$, Ali Rıza Özcan ${ }^{32}$, İzzet Kumbaracılar ${ }^{33}$ ve M. Burak Çetintaş ${ }^{34}$ ise "darda-

${ }^{24}$ Kemal Beydilli, "Yeniçeri”, 461.; Miyase Koyuncu Kaya, "Esnaf Loncalarında Yeniçeriler”, History Studies 5/4, (2013): 189.

25 Sena Yavuz, Sakarya Ili Geyve İlçesi Osmanlı Dönemi Mezar Taşları, (Yüksek Lisans Tezi: Sakarya Üniversitesi, 2013), 286.

26 Hamza Gündoğdu ve Zeki Yılmaz, “Çorlu'da Fatih Camii ve Haziresindeki Mezar Taşları”, Geleneksel Türk Mezar Taşları I. Ulusal Sempozyumu (24-26 Mart 2017), (Aydın: Erciyes Üniversitesi Yayınları, 2017), 168-169.

27 Tülin Çoruhlu ve Murat Alkan, "Sakarya/Kocaali İlçesi Osmanlı Dönemi Mezarlıkları ve Mezar Taşları”, Geleneksel Türk Mezar Taşları I. Ulusal Sempozyumu, (Kayseri: Erciyes Üniversitesi Yayınları, 2017), 561.

28 M. Burak Çetintaș, "istanbul Mezarlıklarındaki ve Hazirelerindeki Yeniçeri Mezar Tașları ile Yeniçeri Mezar Taşlarının Bazı Hususiyetleri”, Imparatorluk Başkentinden Kültür Başkentine İstanbul, (İstanbul: Kitâbevi Yayınları, 2010), 231.

29 Halit Çal, "Türklerde Mezar - Mezar Tașları", 131-132.

30 Hans Peter Laqueur, Hüve'l Baki İstanbul'da Osmanlı Mezarlıkları ve Mezar Taşları. çev. Selahattin Doludizgin, (İstanbul: Tarih Vakfı Yurt Yayınları, 1997), 147-149.; adlı yayında "İstanbul'da en çok rastlanılan serpûşlardan birisidir ve yapılması oldukça basittir" şeklinde belirtilmiştir.

31 İșli ve Kökrek. Yeniçeriler Remizleri ve Mezar Taşları, 86.

32 Ali Rıza Özcan, İstanbul'un 100 Mezar Taşı, (İstanbul: IBBB Kültür A.Ş. Yayınları, 2012), 11, 74.

${ }^{33}$ Kumbaracılar, Serpuşlar, 9.

34 Çetintaş, “ístanbul Mezarlıklarındaki ve Hazirelerindeki Yeniçeri Mezar Taşları ile Yeniçeri Mezar 
ğan" terimiyle tipolojik olarak sınıflandırmıştır.

Bu çalışmada, dardağan ismi ile kaleme alınan serpûşların tipolojik olarak ayrılmasındaki asıl gaye, benzer tipte sarılım özellikleri gösteren serpûşları bir grup altında toplayıp sadeleştirerek değerlendirmektir. Dolayısıyla genelden özele doğru yapılan ayırımda, kitâbelerindeki ibarelere göre sınıflandırma yapmanın en doğru yöntem olacağını düşünüyoruz. Bu düşünceyle incelenen şâhideler, kitâbelerinde beşe ya da serdengeçti gibi herhangi bir meslek zikredilen veya zikredilmeyenler" şeklinde bir tanımlamaya müsteniden tasnif edilmeye çalışılmıştır.
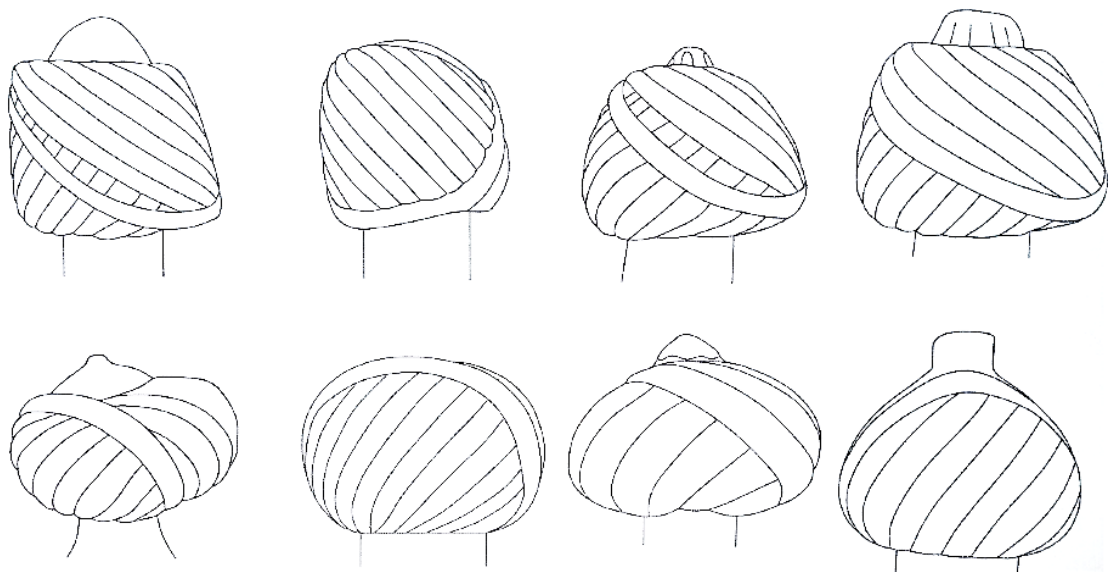

Şekil 2. Dardağan Serpûş Tipleri (N. İşli-M. Kökrek, 2017, 86).



Şekil 3. Dardağan Serpûş Tipleri (H. Peter Laqueur, 1997, 147).

2. Beşe Unvanlı Mezar Taşlarında Dardağan Serpûşlar

\subsection{Beşe Unvanı ve Yeniçeriler}

Lügatta "erkek evlat, büyük evlat ve emîr" gibi anlamlara sahip olan beşe kelimesinin kökeninde bulunan "baş" ve "ağa" kelimelerinden türemiş olduğu düşünülmektedir. ${ }^{35}$ Beşe unvanının bir aşîret büyüğünü veya paşayı ifade ettiğine işaret edilse de, ${ }^{36}$ daha çok yeniçeri ocağının alt birliklerinden birisi olarak zikredilir. ${ }^{37}$ Çünkü ocak içinde bir tertip, rütbe, önem veya değer sıfatlarını tem-

Taşlarının Bazı Hususiyetleri”, 231.

35 Şinasi Acar ve Murat Özveri, "Yaycı Yusuf Beşe Terekesinin Düşündürdükleri”, Osmanlı Bilimi Araștırmaları 9, (2008): 120, 122.

36 Pakalın, Osmanlı Tarih Deyimleri ve Terimleri Sözlüğü 1, 211.

37 Mustafa Akbel, “Tereke Kayıtlarından Hareketle Yeniçerilerin Sosyo-Ekonomik Durumları", Tarihin Peşinde-Uluslararası Tarih ve Sosyal Araştırmalar Dergisi 15, (2016): 264. 
sil edecek şekilde kullanılmıştır. Nitekim Şenyurt'un arşiv kayıtlarında tespitini yaptığı taşçı esnafının örgütlenmesiyle ilgili çalışmasındaki bir detay bu kullanımı destekler mahiyettedir. Şenyurt'a göre, taş almasına izin verilenler arasında "beşe" unvanına sahip taşçılar mevcut olup, bunların aynı zamanda yeniçerilik berâtına sahip kişiler oldukları düşünülmektedir. Ancak, Şenyurt'un kullandığı belgedeki taşçı remizleriyle mevcut yeniçeri remizlerinin karşılaştırılması ve kayıtlarda Zeyneb Beşe adında bir kadın taşçının adının verilmesi ${ }^{38}$ gibi unsurlar, beşenin bir meslek mi yoksa bir unvan mı olduğu konusunda karar vermeyi zorlaştırmaktadır.

Eğer bir mesleki unvansa o zaman acaba taşçı esnafından biri miydi? Eğer taşçılardan ise o zaman acaba kadınlardan beşe olabilir miydi gibi sorular cevap beklemektedir. Diğer yandan eğer bir yeniçeri unvanıysa o zaman acaba sayğın bir yeniçeri ağası mıydı yoksa ocağın alt sınıfından biri miydi sorularını belgeleriyle cevaplamak gerekmektedir. Nitekim bu belirsizliği destekler mahiyette çalışmalar da mevcuttur. Bunlardan birinde, 17. yüzyılda bu unvanın yeniçeriler dışında da kullanıldığı belgelerle ispat edilmiştir. ${ }^{39}$ Bu tespit mezar taşı araştırmaları için oldukça mühimdir. Çünkü bugüne kadar birçok şâhide, kitâbesinde "beşe" ibaresi geçtiği için yeniçerilere isnat edilmiş ve sahibi yeniçeri olarak değerlendirilmiştir. Hatta "beşe ibaresi sadece yeniçeriler arasında kullanılan bir unvan olduğu için bu ibarenin bulunduğu her şâhidenin bir yeniçeriye ait olduğunu gösterir"40 gibi oldukça iddialı hükmî genellemelerin yapıldığı da malumdur.

Her ne kadar "Dergâh-ı âli yeniçerilerinden" şeklinde başlayan tanımları, beşe unvanı takip etse ve bu kayıt mezkûr kişinin yeniçeri teşkilatının bir mensubu olduğunu gösterse de arşiv kayıtlarının geneli dikkate alındığında bu unvanın her zaman yeniçeriler için kullanılmadığı anlaşımaktadır. Çünkü beşenin ağabey ya da keyifli insan anlamında, kişilerin halk nezdindeki saygınlığına göre verilmiş bir unvan olduğu da düşünülmektedir. Bunun yanında, tertip ve nizamın bozulmasıyla yeniçerilerin kışladan çıkmaları, onların esnaf birlikleri arasına karışmalarına ve esnaf arasında beşe unvanı veya adıyla ilgili karışıkığın oluşmasına ortam hazırlamış olma ihtimali de göz önünde bulundurulmalıdır. ${ }^{41}$ Nitekim bizim Sakarya araştırmamızda, çok sayıdaki yeniçeri mezar taşında farklı meslek gruplarının kayıtlı olduğu görülmüştür. Bunların Sakarya ilçelerindeki dağılımına bakıldığında, unvan sahibi kişilerin şehirde veya köyde yaşayan diğer insanlardan pek farklı olmadığı da pekâlâ düşünülebilir. Ayrıca bunlar, serpûşlarından hareketle, 1726-1822 yılları arasında, o zamanlar İzmit Sancağına tâbi olan Adapazarı ve havalisine yayılım gösteren nüfusun nitelikleri yanında, yeniçerilerin nüfus içindeki dağılımını veren birer belge olarak da değer-

\footnotetext{
38 Oya Şenyurt, “Onsekizinci Yüzyıl Osmanlı Başkentinde Taşçı Örgütlenmesi”, METU JFA 26:2, (2009): 110, 117.

39 Turan Açık, “Beşe Unvanı Hakkında”, Tarih Dergisi 62/2, (2016): 37-64.

40 Mehmet Kökrek, “Edirne'deki Yeniçeri Şâhideleri”, Türk Dünyası Tarih Kültür Dergisi, 2015, s. 31, 32.

41 Turan Açık, “Beşe Unvanı Hakkında”, 47,52,57.
} 
lendirilebilir. ${ }^{42}$ Sakarya mezar taşlarında dardağan serpûşların incelemesine geçebiliriz.

\subsection{Sakarya Mezar Taşlarında Beşe Unvanı ve Dardağan Serpûşlar}

Sakarya ilinin merkez dâhil 14 ilçesinde, toplam 47 mezarlıkta yapılan saha çalışmasında 119 adet dardağan serpûş tespit edilmiştir. Kitâbelerinde beşe unvanı kayıtlı şâhide sayısı ise, 18. yüzyılın ilk yarısından 5, aynı yüzyılın ikinci yarısından 15, 19. yüzyılın ilk yarısından 14 ve 2 adet de tarihsiz olmak üzere toplam 36 adettir. ${ }^{43}$

Tablo 1. Sakarya Mezar Taşlarında "Beşe" Unvanlı Kitâbeler

\begin{tabular}{|c|c|c|c|}
\hline Sayı & YII & Kitâbe Metinleri & Serpûşlar \\
\hline 1. & 1739 & $\begin{array}{l}\text { Merhûm Beyaz, Muhammed Beşe rû-, -huna } \\
\text { Fâtiha, Sene } 1152\end{array}$ & Dardağan \\
\hline 2. & 1739 & $\begin{array}{l}\text { Merhûm ve mağfurMuhammed Beşe rûhuna el- } \\
\text { Fâtiha, Sene } 1152\end{array}$ & Dardağan \\
\hline 3. & 1739 & $\begin{array}{l}\text { Merhûm Osman, Beşe rûhuna, Fâtiha / Sene } \\
1152\end{array}$ & Dardağan \\
\hline 4. & 1742 & $\begin{array}{l}\text { Merhûm Otuz, Iki Bölüğün İbrahim Beşe Rûhuna } \\
\text { Fâtiha, Sene } 1155\end{array}$ & Dardağan \\
\hline 5. & 1744 & $\begin{array}{l}\text { Kurşundan şehit, Ölen merhûm Mustafa Beşe, } \\
\text { Rûhuna Fâtiha, Sene } 1157\end{array}$ & Dardağan \\
\hline 6. & 1755 & Merhûm Halîl, Beşe rûhuna, Fâtiha, Sene 1169 & Dardağan \\
\hline 7. & 1765 & $\begin{array}{l}\text { el-Muhtâc ilâ rahmet-i, Rabbihî'l-Ğafûr, Hacı } \\
\text { İmamzâde, Süleyman Beşe oğlu, Muhammed } \\
\text { Beşe ruhuna, Fâtiha Sene } 1179\end{array}$ & Dardağan \\
\hline 8. & 1770 & $\begin{array}{l}\text { Merhûm ve mağfur, el-Muhtâc ilâ rahmet-i Rab- } \\
\text { bihî, el-Ğafûr Abdi Bey, Oğlu Abdurrahman Beşe, } \\
\text { Rûhuna Fâtiha / Sene } 1184\end{array}$ & Yok \\
\hline 9. & 1771 & $\begin{array}{l}\text { Merhûm ve mağfur, Muhammed Beşe ruhuna, } \\
\text { el-Fâtiha, Sene } 1185\end{array}$ & Dardağan \\
\hline 10. & 1772 & $\begin{array}{l}\text { Merhûm ve mağfur, Mahmûd Beşe, rûhuna } \\
\text { Fâtiha, Sene } 1186\end{array}$ & Dardağan \\
\hline 11. & 1776 & $\begin{array}{l}\text { Merhûm ve mağfur, Süleyman Beşe, Rûhuna } \\
\text { Fâtiha, Sene } 1190\end{array}$ & Dardağan \\
\hline 12. & 1780 & $\begin{array}{l}\text { Fenâdan bekâya eyledi rıhlet, Ede Hak kabrini } \\
\text { ravza-i cennet, Şaban Beşe oğlu, Merhûm Hüse- } \\
\text { yin Beşe, Rûhuna Fâtiha, Sene } 1195\end{array}$ & Dardağan \\
\hline 13. & 1780 & $\begin{array}{l}\text { Gençliğine doymayan, Murâdına ermeyen, } \\
\text { Kazâen merhûm olan, Hasan oğlu Abdullah Be- }\end{array}$ & Dardağan \\
\hline
\end{tabular}

421831 Yılında İzmit Sancağı toplam nüfusunun 16.236 olduğu bilinmektedir. Bkz. Nilüfer Edecin, Sakarya'da Nüfus Hareketleri, (Yüksek Lisans Tezi: Sakarya Üniversitesi, 2007), 18.

${ }^{43} \mathrm{Bu}$ yüzyıllarında şâhidelerin dönem özellikleri hakkında ayrıntılı bilgi için bknz; Lütfi Şeyban ve Oktay Gündoğdu, "Sakarya Mezar Taşlarının Tarihi Dizin ve Dönem Analizleri”, Akademik incelemeler Dergisi 15/2, (2020): 3-13. 


\begin{tabular}{|c|c|c|c|}
\hline & & şe, Rûhuna Fâtiha / Sene 1195 & \\
\hline 14. & 1786 & $\begin{array}{l}\text { Merhûm ve mağfur, Köroğlu Hüseyin Beşe ruhu- } \\
\text { na, Sene } 1201\end{array}$ & Dardağan \\
\hline 15. & 1787 & $\begin{array}{l}\text { Hüve'I-Bâkî, Merhûm ve mağfur, el-Muhtâc ilâ } \\
\text { rahmet-i, Rabbihî'l-Ğafûr Karabıçak, Feyzullah } \\
\text { Beşe, Rûhuna el-Fâtiha, Sene } 1202\end{array}$ & Dardağan \\
\hline 16. & 1793 & $\begin{array}{l}\text { Hüve'I-Bâkî, Merhûm ve mağfur, Mecâz-oğlu Ali, } \\
\text { Beşe rûhuna Fâtiha, Sene } 1208\end{array}$ & Yok \\
\hline 17. & 1793 & $\begin{array}{l}\text { Hüve'I-Bâkî, Ziyaretten murâd bir duâdır, Bugün } \\
\text { bana ise yarın sanadır, Merhûm ve mağfûr Şeyh, } \\
\text { Oğlu Memiş Beşe'nin, Rûhuna Fâtiha, Sene } \\
1208\end{array}$ & Dardağan \\
\hline 18. & 1793 & $\begin{array}{l}\text { Gülviran'lı Molla, Mahmûd oğlu ecel-i, Kazâ ile } \\
\text { vefât, Eden merhûm Mehmed, Beşe rûhuna } \\
\text { Fâtiha, Sene } 1208\end{array}$ & Dardağan \\
\hline 19. & 1793 & $\begin{array}{l}\text { Hüve'l-Bâkî, Doymayıp gençliğine çünkü Oldu } \\
\text { nâmurâd rahmete müstağrak, Ede onu Rabbü’l- } \\
\text { ibâd, Kuru Beşe oğlu merhum, Mustafa Beşe } \\
\text { ruhuna, Fâtiha sene } 1208\end{array}$ & Dardağan \\
\hline 20. & 1798 & $\begin{array}{l}\text { Merhûm ve mağfur, Seyyid Ahmed Beşe, Rûhu- } \\
\text { na Fâtiha, Sene } 1213\end{array}$ & Dardağan \\
\hline 21. & 1800 & $\begin{array}{l}\text { Çünkü ömrüm tamam oldu, Benden size selam } \\
\text { olsun, Tuz etmek yediğim dostlara, Âhiret hakkı } \\
\text { halâl olsun, Yürü hey bî-vefâ dünya, Sana da el- } \\
\text { veda olsun, Kürt Hacı Alinin oğlu, Merhûm Mus- } \\
\text { tafa Beşe, Rûhuna Fâtiha, Sene } 1215\end{array}$ & Dardağan \\
\hline 22. & 1801 & $\begin{array}{l}\text { Merhûm ve mağfur, Molla-oğlu, Halîl Beşe, } \\
\text { Rûhuna Fâtiha, Sene } 1216\end{array}$ & Sarıklı \\
\hline 23. & 1803 & $\begin{array}{l}\text { Hüve'I-Bâkî, Gel ziyaret eyle kabrim hâris olma } \\
\text { dünyaya, Yarın nöbet sana gelir gâfil olma fena- } \\
\text { ya, Gençliğine doymayıp göçtü cihandan, Sebeb- } \\
\text { i mevtim mübarektir emirim var, Hüdâ'dan, Hi- } \\
\text { dayet olsa şühedâlık Mevlâ'dan, Unutmayınız bu } \\
\text { Merhûmu duadan, Tuzcu Muhammed oğlu mer- } \\
\text { hum ve mağfûr Hasan Beşe'nin, Rûhu îçûn } \\
\text { rızâen, Li'llâhi Teâlâ el-Fâtiha, Fî gurre-i Cemâzi- } \\
\text { yelâhir sene } 1218\end{array}$ & Dardağan \\
\hline 24. & 1804 & $\begin{array}{l}\text { Karaçomakoğlu, Abdülfettâh, Beşe rûhuna, } \\
\text { Fâtiha sene } 1219\end{array}$ & Dardağan \\
\hline 25. & 1805 & $\begin{array}{l}\text { Bizden size selam olsun, Tuz etmek yediğim } \\
\text { dostlara, Âhiret hakkı halâl olsun, İsa oğlu Kürt, } \\
\text { Merhûm ve mağfûr Osman, Beşe'nin rûhuna el- } \\
\text { Fâtiha, Sene } 1220\end{array}$ & Dardağan \\
\hline
\end{tabular}




\begin{tabular}{|c|c|c|c|}
\hline 26. & 1807 & $\begin{array}{l}\text { Merhûm ve mağfur, İlâ Rabbihî'l-Gafûr, Şeker } \\
\text { oğlu Ali, Beşe rûhuna Fâtiha, Sene } 1222\end{array}$ & Dardağan \\
\hline 27. & 1807 & $\begin{array}{l}\text { Merhûm ve mağfûr, Hacı oğlu, Hüseyin Beşe, } \\
\text { Rûhuna Fâtiha, Sene } 1222\end{array}$ & Dardağan \\
\hline 28. & 1811 & $\begin{array}{l}\text { Merhûm ve mağfur, Ca'fer oğlu, Osman Be- } \\
\text { şe'nin, Rûhuna Fâtiha, Sene } 1226\end{array}$ & Dardağan \\
\hline 29. & 1812 & $\begin{array}{l}\text { Gençliğine doymayan, Murâdına ermeyen, } \\
\text { Merhûm ve mağfur, Illâ rahmet-i Rabbihî̀l-Ğafûr, } \\
\text { Himmet Ağanın oğlu, Muhammed Beşe rûhuna, } \\
\text { el-Fâtiha, Sene } 1227\end{array}$ & Dardağan \\
\hline 30. & 1813 & $\begin{array}{l}\text { Ziyaretten murâd bir duâdır, Bugün bana ise ya- } \\
\text { rın sanadır, Merhûm Cepçi-oğlu, Ali Beşe ruhu- } \\
\text { na, el-Fâtiha sene } 1229\end{array}$ & Dardağan \\
\hline 31. & 1814 & $\begin{array}{l}\text { Merhûm ve mağfur, Nebioğlu Yeniçeri, Muham- } \\
\text { med Beşe'nin, Rûhuna el-Fâtiha, Sene } 1229\end{array}$ & Dardağan \\
\hline 32. & 1815 & $\begin{array}{l}\text { Ziyaretten murât bir duâdır, Bugün bana ise ya- } \\
\text { rın sanadır, Merhûm ve mağfur, Feyzullah Be- } \\
\text { şe'nin, Rûhuna el-Fâtiha, Sene } 1231\end{array}$ & Abani Sarık \\
\hline 33. & 1815 & $\begin{array}{l}\text { Merhûm ve mağfur, Kaymaslı Ali Beşe, Rûhîçûn } \\
\text { Fâtiha, Sene } 1231\end{array}$ & Dardağan \\
\hline 34. & 1819 & $\begin{array}{l}\text { Ziyaretten murâd bir duâdır, Bugün bana ise ya- } \\
\text { rın sanadır, Merhûm ve mağfur, Hatîb Hüseyin, } \\
\text { Beşe rûhuna Fâtiha, Sene } 1235\end{array}$ & Dardağan \\
\hline 35. & Yok & $\begin{array}{l}\text { Merhûm ve mağfur, Illâ rahmet-i Rabbihî'l-Ğafûr, } \\
\text { Lazoğlu Ahmed Beşe, Rûhîçûn, Fâtiha.... }\end{array}$ & Dardağan \\
\hline 36. & Yok & $\begin{array}{l}\text { Hüve'I-Bâkî, Merhûm ve mağfur, Gençliğine } \\
\text { doymayan, Koca Ömer oğlu, Mustafa Beşe'nin, } \\
\text { Rûhuna Fâtiha }\end{array}$ & Dardağan \\
\hline
\end{tabular}

Tespit edilen "beşe" unvanlı kitâbelerin veriliş amacı dönem analizi yapmaktır. Bu tabloda görüldüğü üzere 1739-1755 arasında metfun kişilerin tanımlamaları oldukça sade tutulurken, geç tarihli olanlarda edebi bir dil kullanımı yanısıra, aile efradı ve ölüm nedeni gibi bilgilerin yazılı olduğu görülmektedir. Sonraki tarihlere ait örneklerde ise, önce beşe unvanı baba adıyla birlikte anımaya başlanmakta ve ardından şiir, dua, istek ve ölüm nedeninin belirtildiği kısımlar gelmektedir. Fakat aynı tarih aralığına ait İstanbul ve Bursa'daki mezar taşı örnekleri üzerinden bakıldığında, bunlarda daha yoğun bir edebi doku ya da düzenin hâkim olduğu görülmektedir. Bu bilgiyi vermemizin amacı, dardağan serpûşa sahip şâhide örneklerinin kimlikleri konusunda henüz kesin bir sonuca varılamamış olduğunu belirtmek ve de "dardağan serpûşlu beşe unvanı” şâhidelerde kitâbelerin sade tutulup tutulmadığını sorgulamaktır. Nitekim Sakarya sahasından elde edilen verilerde "Nebioğlu Yeniçeri" ve "Muhammed Beşe" şeklinde kayıtı iki örnek dışında Yeniçeri ismiyle tanıtılan başka örnek bulunmamaktadır. Bunun yanısıra beşe grupları arasında, kitâbesinde "Otuz İki Bölüğün” askerlerinden olduğu kayıtlı tek örnek ibrahim Beşe'nin mezar taşıdır. 
Ayrıca bu türden mezar taşlarının genel özelliklerine bakıldığında, tamamının erkek metfun, Celî Sülüs hatla nakşedilmiş, süslemesiz olduğu; ayrıca birçoğunun ser-levha kısmında "Hüve'l-Bâki" ve "Merhûm ve mağfur" ibarelerinin kullanıldığı tespit edilmiştir.

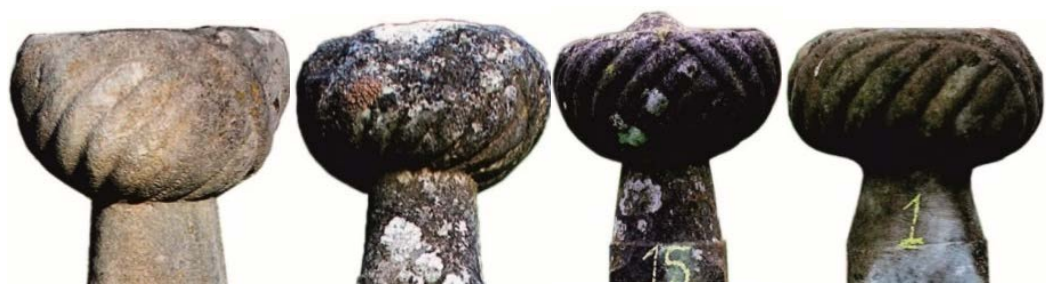

Şekil 4. 1739, 1739, 1742, 1745.
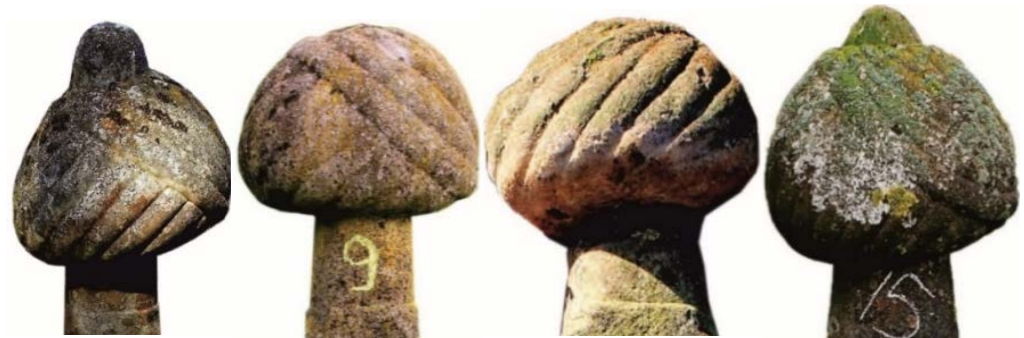

Şekil 5. 1765, 1771, 1776, 1780.
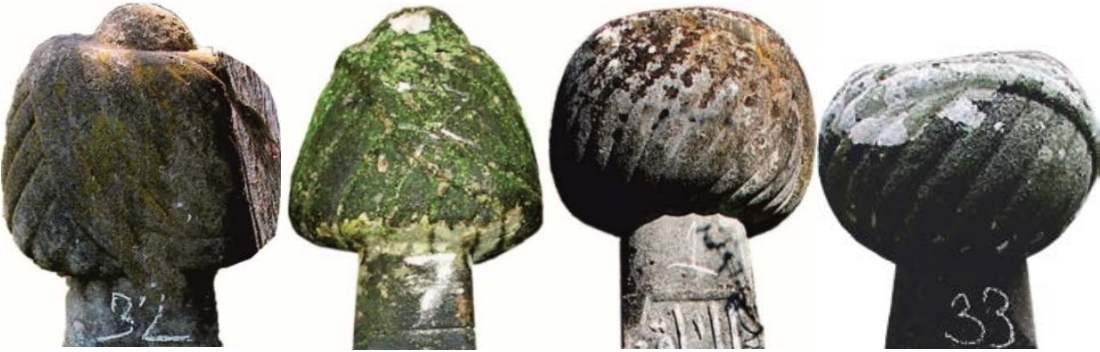

Şekil 6. 1780, 1786, 1787, 1793.
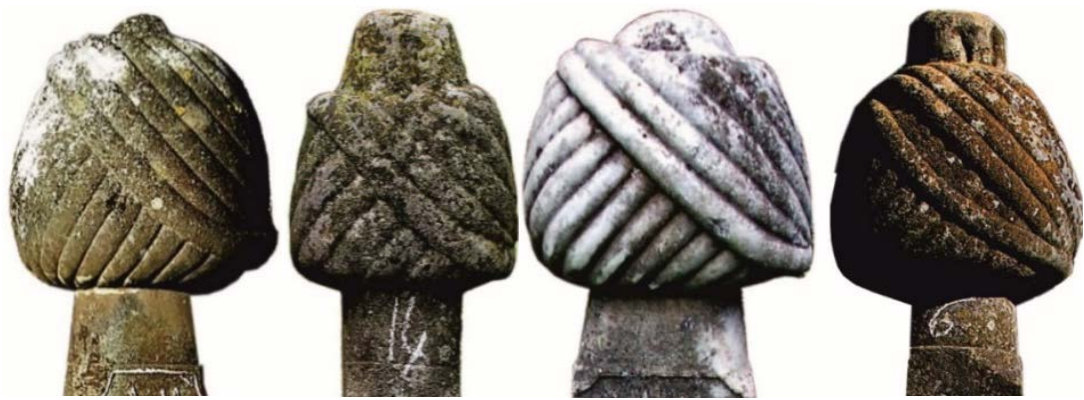

Şekil 7. 1793, 1793,1798, 1800. 



Şekil 8. 1802, 1802, 1803, 1805.
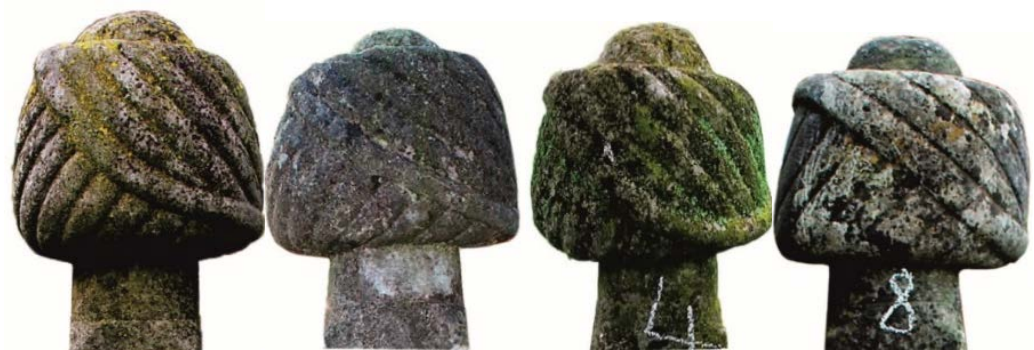

Şekil 9. 1807, 1807, 1811, 1814.
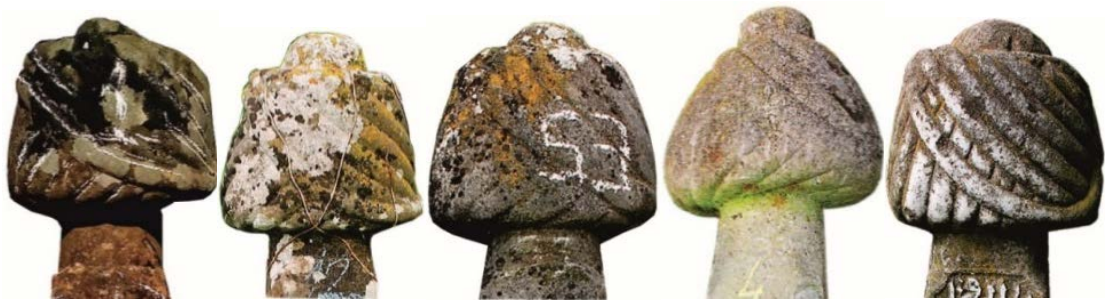

Şekil 10. 1814, 1816, 1819, Yok, Yok.

\subsection{Serdengeçti Unvanlı Mezar Taşlarında Dardağan Serpûşlar}

Serdengeçtiler, yeniçeriler içerisinde en korkusuz akıncı fedai gruplardan birisidir. Bu grubun temel görevi, düşman ordusunun içine sızmak ve kaleleri içeriden ele geçirmektir. ${ }^{44}$ Hedefine tereddütsüz odaklanmayı ve atılmayı yüksek bir beceriye dönüştürmüş, ayrıca görev uğrunda başa gelebilecek ömrün tükenmesi ve şehadet gibi her duruma zihnen ve bedenen hazırlıklı olma bilincine sahip olmalarından dolayı kendileri serdengeçti olarak anılmıştır. Serdengeçtilerin muharebelerde öngördükleri tek sonuç, ölümün muhakkak olduğuydu. Girdikleri çetin görevlerde sağ kalanlara, özel bir ödül olması bakımından para veya serdengeçti namlı başlığı kullanması hakkı verilirdi ki, bu sayede hem kurumsal kimlikleriyle yeniçerilerden ayrılmış oluyorlar hem de görevlerinin kendilerine kazandırmış olduğu saygınlık ve hürmete kavuşmuş oluyorlardı. Ayrıca içlerinden bazıları "Serdengeçti Ağası" sıfatıyla anılmaya başlardı. ${ }^{45}$

Dardağan başlığın türevlerinden birisi olan serdengeçti unvanlı mevtâların serpûşları, külahının dar ve konik olması nedeniyle tüm yeniçeri serpûşları içe-

44 Pakalın, Osmanlı Tarih Deyimleri ve Terimleri Sözlüğü 1, 38, 243.

45 Pakalın, Osmanlı Tarih Deyimleri ve Terimleri Sözlüğ̈̈ 3, 390, 243. 
risinde en farklı ve ayırıcı tipi oluşturmaktadır. ${ }^{46}$ Serpûş üzerinde destarların oluşturduğu soldan sağa doğru açılı yükselen asimetrik sarma düzeniyle de diğer serpûşlardan tip olarak ayrışmaktadır. ${ }^{47} \mathrm{Bu}$ arada, yeniçeriler içerisinde sadece serdengeçtilerin sorguç kullandıkları biliniyor ki serpûşlarda bu detaylar da görülebilmektedir. ${ }^{48}$ Sonuçta, Serdengeçti serpûşlar, yeniçerileri doğrudan temsil eden serpûşlar arasında yer alıp dardağan serpûşa benzemektedir. ${ }^{49}$ Serpûş olarak dardağan grubu içinde ele alınmasının nedeni ise, destarların bir diğerini kesmesidir ki, aynı düzenleme dardağan grubu içeresinde de görülmektedir. Bunların serdengeçti olarak sınıflandırılmasının en önemli nedeni de kitâbelerinde unvanlarının vurgulanmasıdır.

Serdengeçti serpûşları, dardağan başlığın geniş destar düzenine nazaran daha incedir ve sık sarılmıştır ${ }^{50}$. H. N. İşli ve M. Kökrek tarafından yapılan çaIışmadan analiz edildiği üzere, toplamda 13 serdengeçti mezar taşından hiçbirisinde unvanı verilmezken bazılarında "Tarakçı, sipahi, debbağ, çadır başı, 548-17. bölük yoldaşı" şeklinde meslekler belirtilmiştir. Bu detaylar bizlere serdengeçti unvanlı yeniçerilerin aynı zamanda başka işlerle ilgilendiklerini doğrulayıcı birinci elden kimlik kayıtları sağlamaktadır. Halit Çal'ın bölgesel çalışmaları sonucu yaptığı değerlendirmesine göre, "Karadeniz bölgesi ağırlıklı olmak üzere ve Anadolu örneklerinde Serdengeçti Ağaları ve yeniçerilerle ilgili meslek mensupları varken, başkent örneklerinde yeniçerileri görmek mümkündür. 1688 yılında teşkilatın kaldııımış olmasına rağmen 19. yüzyılın başlarına kadar görülebiliyor." 51

Sakarya sınırları içerisinde yapılan saha çalışmasında Tarakı-Yunus Paşa Cami Haziresinde iki adet ve Pamukova-Orta Mezarlık alanında bir adet olmak üzere toplamda 3 serdengeçti unvanlı kitâbeye sahip şâhide tespit edilmiştir. Sakarya'da bulunan bu 3 şâhide içerisinde serdengeçti unvanlı olup bağlı olduğu kısmı veren tek örnek, 1794 tarihli Elli Sekiz Cemaatin Serdengeçti Ağası Kolçak el-Hâc Muhammed Ağa'dır. Şâhidesinde herhangi bir remiz bulunmamaktadır. 18. yüzyıl sonlarına tarihlenen bu şâhidelerin genel özelliklerine bakıldığında, ser-levha bölümlerinde teslimiyet ifadesi olarak "Hüve'l-Bâki" ve “Hüve'l-Hallâku'l-Bâkî”, gövde bölümünde yoğun bir edebi dille dünyanın fâniliği, dua talebi, Allah'tan af ve mağfiret dileme kayıtlıdır. Kişinin tanıtıldığı son bölümde ise Serdengeçti unvanıyla birlikte varsa bölüğü ve ismi verilmiştir. Tespit edilen 3 şâhidenin kitâbeleri Celî Sülüs hatla mahtût olup, üzerlerinde süsleme bulunmamaktadır. Dardağan serpûş olarak değerlendirilmesinin asıl nedeni ise, birbirine olan tip benzerlikleri nedeniyle bunları genel bir serpûş altında toplama intiyacıdır. Çünkü Serdengeçti terimini bir unvan olarak esas alıp de-

\footnotetext{
46 Eldem, “Yeniçeri Mezartaşları Kitabı Vesilesiyle Yeniçeri Taşları ve Tarih Üzerine”, 10.

47 Laqueur, Hüve'l Baki istanbul'da Osmanlı Mezarlıkları ve Mezar Taşları, 147.

48 Pakalın, Osmanlı Tarih Deyimleri ve Terimleri Sözlüğü 3, 243.

49 Kökrek, "Osmanlı Serpuşları", 50-51.

50 isşli ve Kökrek. Yeniçeriler Remizleri ve Mezar Taşları, 106.

51 Çal, "Türklerde Mezar - Mezar Taşları", 311.; Pakalın, Osmanlı Tarih Deyimleri ve Terimleri Sözlüğü 3, 390. Adlı yayında ise Yeniçeri ocağının kaldırılmasıyla bu tabirin sona erdiği belirtilmiştir.
} 
ğerlendirme yapıldığında serpûş, kendi hüviyetinden ayrılacaktır. Nitekim diğer serpûşların hiçbirisi hem bir unvan hem de serpûş yönüyle ele alınmamaktadır. Örneğin dalkılıç unvanıyla bilinen bir serpûş bulunmamaktadır.

Tablo 2. Sakarya Mezar Taşlarında Serdengeçti Unvanlı Kitâbeler

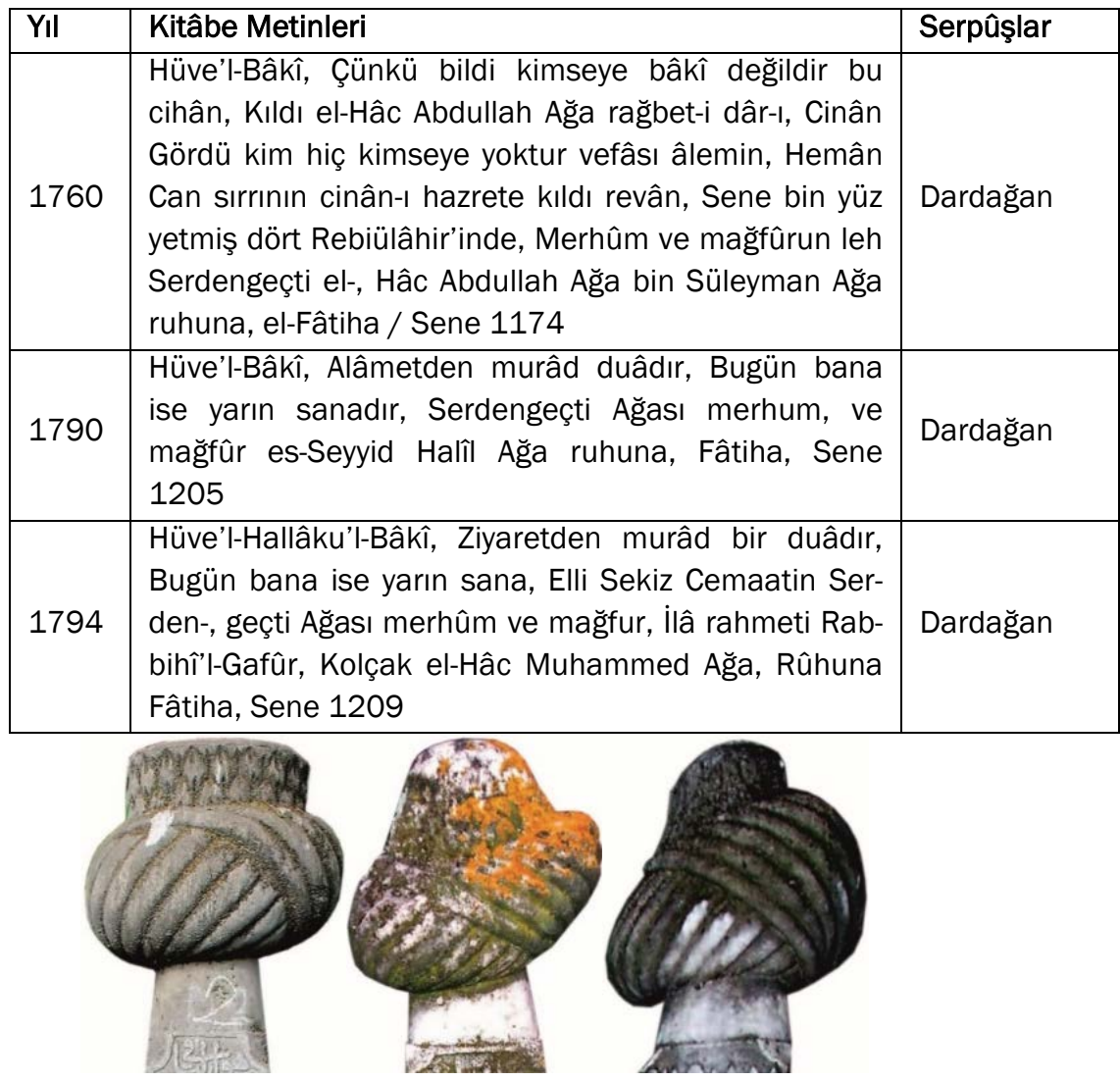

Şekil 11. 1760, 1790, 1794.

\subsection{Kitâbelerinde Meslek Kaydı Bulunan Dardağan Serpûşlar}

Mezar taşlarında kitâbeler hüviyet veren birincil kaynaklardır. Metfun kişinin şeceresi, doğum ve ölüm tarihleri ve bağlı olduğu meslek grupları gibi çok çeşitli verileri saklayan alanlardır. Bu kısımda, Sakarya genelinde dardağan serpûş bulunan mezar taşlarının kitâbeleri analiz edilerek Yeniçeri teşkilatına mensubiyetleri sorgulanmaya çalışılacaktır.

Analizi kolaylaştıran bir unsur olarak, Sakarya mezar taşlarında dardağan serpûş örnekleri tip olarak çeşitlilik ve zenginlik arz etmektedir. Meslek tespiti bakımından yaklaşıldığında, benzer tipteki dardağan serpûşlara bakılarak hangisinin yeniçeri olduğunu anlamak hiç kolay değildir. Çünkü bu serpûşların bazılarında meslek bilgisi kayıtıyken diğer bazılarında kayıtlı değildir. Fakat şâhidelerin meslek tasnifleri yapıldıktan sonra hem yeniçerilere atfedilen dardağan serpûşların başka meslekler tarafından da kullanıldığı hem de yeniçeri olduğu 
anlaşılanların meslek dışı faaliyetlerinin neler olduğu görülecektir. Ayrıca bu tür tasniflerin, meslek grupları ve serpûş çeşitleri konusundaki çalışmaları besleyeceği de düşünülebilir. Diğer yandan, yeniçeri bölüklerine ait numaraların mukayyet olduğu bir şâhidenin serpûş kısmının dardağan olması, meslek gruplarına göre tasnif yapmanın önemini de ortaya koymaktadır. Şimdi bu tasnife dair örnekler verebiliriz.

Dardağan serpûşlu 23 şâhidenin kitâbelerinde meslekler çavuş, molla, sünnetçi, vakıf idarecisi, minareci, hatip, reis, helvacı, pehlivan, imam-hatip, berber, damacı ve hâkim şeklinde kayıtlıdır. Bu veriler dikkate alındığında, bir yeniçerinin hem asker hem de hâkim olması pek mümkün görülmez. Dolayısıyla bu serpûşları bir teşkilat alameti görmek yerine meslek üzerinden aktarmak daha değerlendirilebilir olacaktır. Mesela Karasu Köyü Merkez Mezarlığında 1748 tarihli "elli altı bölüğü”, Adapazarı Salmanlı/Kaymas Mezarlığında 1754 tarihli “kırk dokuz bölük”, Taraklı Kemaller/Dodurga Mezarlığında 1759 tarihli "elli sekiz cemaat", Sapanca Kemer Mezarlığında 1759 tarihli "kırk dört bölük" şeklinde kayıtlı bulunan toplam 4 şâhidenin kitâbesinde belirtilen bu meslek grupları dikkat çekicidir. Çünkü kitâbelerde yeniçeri teşkilatına olan mensubiyet, bölük ve cemaat kaydı üzerinden belirtilmiştir. Bunlar arasında dardağan serpûşlular 1759 tarihli olanlardır. Üzerinde serpûş bulunmayan diğer şâhideler içinde de bu türden bir serpûşa sahip olanların bulunması intimali güçlüdür. Bu dört mezar taşının üzerinde herhangi bir remiz bulunmamakta ancak, tanımlanan bölükler ile cemaatlerin remizlerini, yayımlanmış araştırmalardan takip edebiliyoruz. ${ }^{52}$

Tablo 3. Kitâbelerde Tespit Edilen Bölük ve Cemaat Adları - Yeniçeri Remizleri

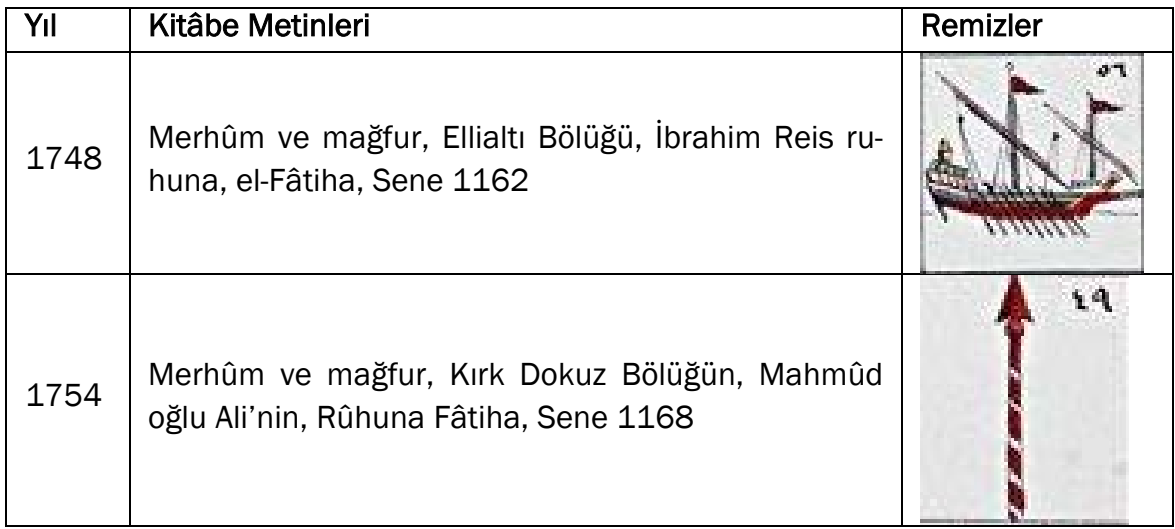

\footnotetext{
52 Mahmut Şevket Paşa, (1907), Osmanlı Teşkilât ve Kıyafet-i Askeriyesi, (İstanbul: Mekteb-i Harbiye
} Matbaası, 1326), 108-109.; Özcan, “Bölük”, 324. 


\begin{tabular}{|l|l|l|}
\hline 1759 & $\begin{array}{l}\text { Hüve'I-Hallâku'I-Bâkî, Merhûm ve mağfûr Kemal, } \\
\text { Zâde Osman Ağanın, Rûhîçûn el-Fâtiha, Sene 1172 } \\
\text { Receb el-ûlâ, Elli sekiz cemâatin, 58 }\end{array}$ \\
\hline 1759 & $\begin{array}{l}\text { Hüve'I-Hayyü'l-Bâkî, Dirîgâa eyledi rıhlet Güççek } \\
\text { Mehmed, Ağanın Bâğ-ı Adn ede menzilini Hayy-ı Ev- } \\
\text { vel-i ilâh, iftirâkıyla yanıp vâlidesi şâm ü sehar, Sabr } \\
\text { ile atasını teskîn eyleye Allah, Merhûm ve mağfûr } \\
\text { Kırkdört, Bölüğün Güççek Mehmed Ağanın, Rûhuna } \\
\text { Fâtiha sene 1173, Cemâziyelûlâ fî 5 }\end{array}$ \\
\hline
\end{tabular}

Tablo 4. Sakarya Mezar Taşlarında Kitâbelerinde Meslek Yazan Dardağan Serpûşlar

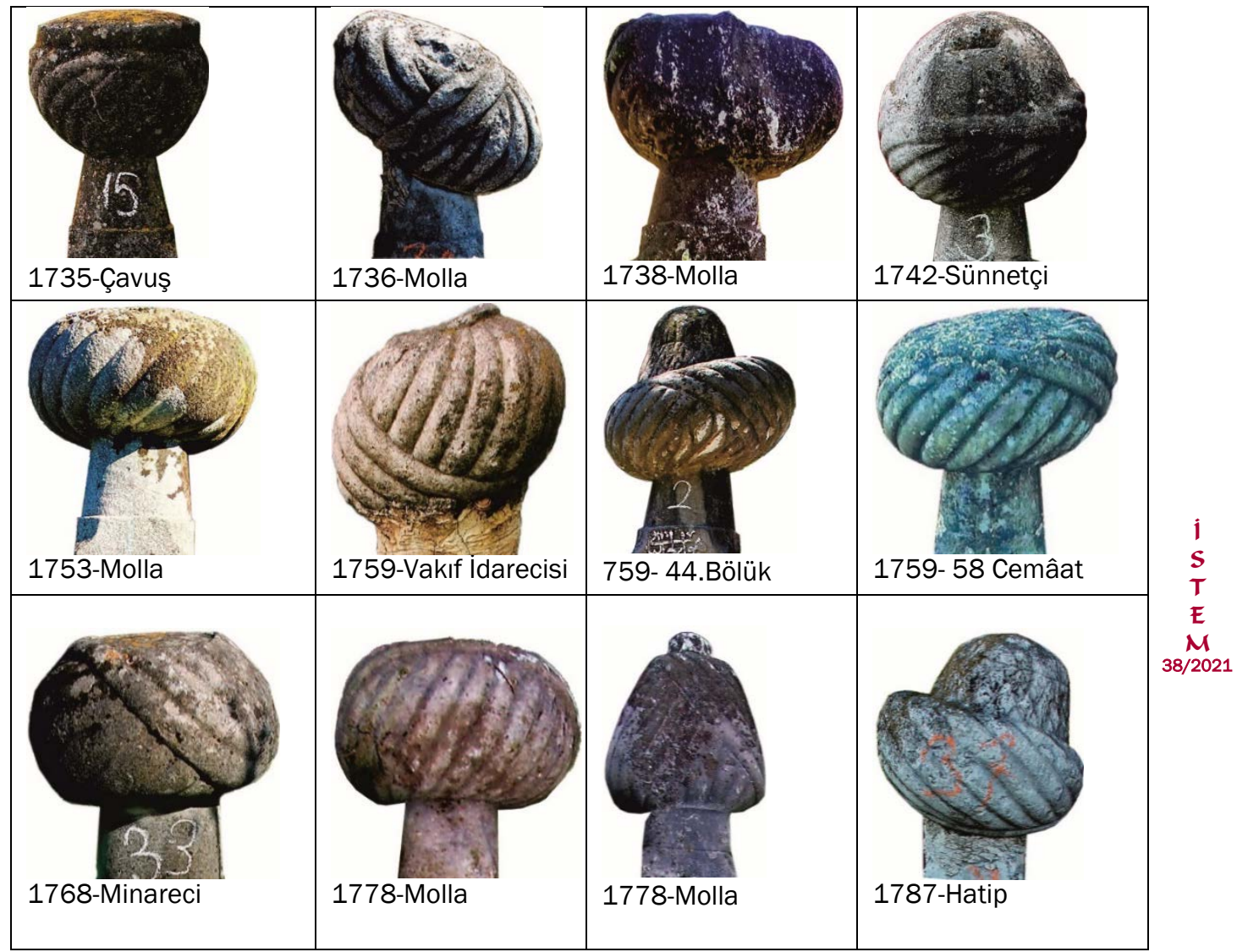






2.5. Kitâbelerinde Mes/ek Kayıtı Olmayan Dardağan Serpûş/ar

Sakarya mezar taşları içerisinde, tespit edilen toplam 119 dardağan serpûşlu mezar taşından 71 tanesinde, meslek grupları belirtilmemiştir. BunIardan 1812 tarihli yalnızca üç şâhidede bulunan ayrıntı verilmiş olup, diğerlerinde serpûşları hâriç herhangi bir yeniçeri alameti bulunmamaktadır. 1812 tarihli olanlarda ise yeniçeri teşkilatından 1. bölüğün remzi bulunmaktadır. Teşkilat içerisinde, ağa bölükleri ismiyle maruf toplam 61 bölük bulunmaktadır. Bunlardan 1. bölük Kethüdâbey makamının olduğu bölüktür53. Verilerin incelenmesi neticesinde, bu bölüğe ait şâhide sayısının az olduğu görülmüştür.

Sakarya ilinde tespit edilen yeniçeri remizli mezar taşları, tek örneklik bakımından önemli olup, alan literatürüne ilk kez bu çalışmayla kazandırılmıştır. Kitâbelerine bakıldığında üç şâhidenin de aynı cümlelerle başladığı, teslimiyetisim-dua ile devam ettiği, ilaveten remizleriyle tarihleri ve hat özelliklerinin de aynı olduğu görülmektedir. Bu şâhidelerden ikisinde kef harfi müsennâ olarak yazılmıştır. Kitâbesinde ve başlığında yeniçeri alameti olmadığı halde, şâhidenin gövdesinde remiz bulunan şâhide örnekleri, belirli bir şemanın takip edilmesi dolayısıyla, bir atölye ve sanatkâr ilişkisine dair tipik bir örneklik teşkil et-

53 Erdoğan Ferit Koyaş, "Yeniçerilerin Orta ve Bölük İşaretlerinin Sembolik Anlamları", Tarih ve Edebiyat Mecmuası 10, (1978): 54 
mektedir. Şâhideler arasındaki temel fark serpûşlarındadır ki, bu detay bize yeniçeri mezar taşlarında serpûşların sadece dardağan serpûştan oluşmadığını, bir ulema başlığının da pekâlâ bir yeniçeriye ait olabileceğini göstermektedir. ${ }^{54}$

Tablo 5. Sakarya Sapanca'da Tespit Edilen 1812 Tarihli Yeniçeri Kitâbeleri

\begin{tabular}{|l|l|l|}
\hline Yıl & Kitâbe Metinleri & Serpûşlar \\
\hline 1812 & $\begin{array}{l}\text { Ilâhî hâcetim bu dergâhından, Inâyet kıl kemâl-i şefka- } \\
\text { tinden, Türâba yüz sürüp geldim niyaza, Beni mahrum } \\
\text { etme rahmetinden, Mustafa Ağanın oğlu, Merhûm Tâhir } \\
\text { Ağa ruhuna, el-Fâtiha, Fî sene 1227 5 Cemâziyelevvel }\end{array}$ & Ulema Sarığı \\
\hline 1812 & $\begin{array}{l}\text { Ilâhî hâcetim bu dergâhından, İnâyet kıl kemâl-i şefka- } \\
\text { tinden, Türâba yüz sürüp geldim niyaza, Beni mahrum } \\
\text { koma rahmetinden, Hüseyin Beşe oğlu merhum ve } \\
\text { mağfûr Süleyman Ağanın, Rûhuna el-Fâtiha, Sene 1227 }\end{array}$ & Dardağan \\
\hline 1812 & $\begin{array}{l}\text { Ilâhî hâcetim bu dergâhından, Inâyet kıl kemâl-i şefka- } \\
\text { tinden, Türâba yüz sürüp geldim niyaza, Beni mahrum } \\
\text { koma rahmetinden, Hacı Ali Ağanın oğlu, Merhûm ve } \\
\text { mağfûr Ahmed Ağa, Rûhuna el-Fâtiha, Sene 1227 }\end{array}$ & Dardağan \\
\hline
\end{tabular}
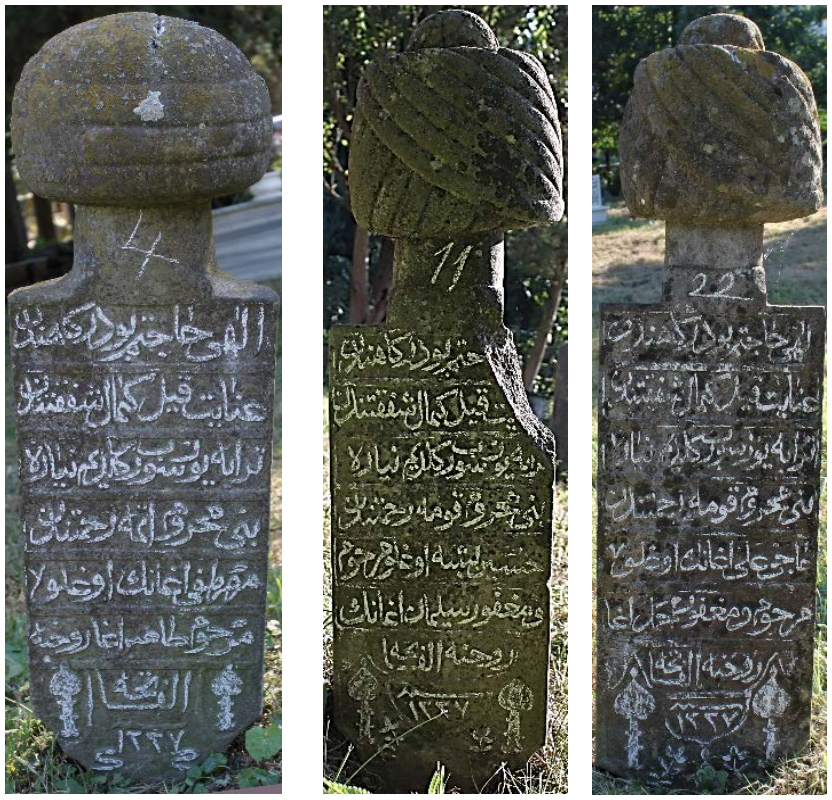

\footnotetext{
${ }^{54}$ Aynı şekilde “Kâtibi (Çiçekçi Cami haziresi 1799-51. Bölük remizli, s.708), Kafesî, Kallavi (s. 700), Sarıklı" serpûşların örneklerine de rastlanılmaktadır. Bilgi ve fotoğraf için bknz; Zeynep Emel EKIM, “Üsküdar ve Yeniçeri Remizleri”, Uluslararası Üsküdar Sempozyumu VII, (İstanbul: Üsküdar Belediyesi Yayınları, 2012), 701,708.; Çetintaș, “istanbul Mezarlıklarındaki ve Hazirelerindeki Yeniçeri Mezar Taşları ile Yeniçeri Mezar Taşlarının Bazı Hususiyetleri”, 235, 245-246.
} 

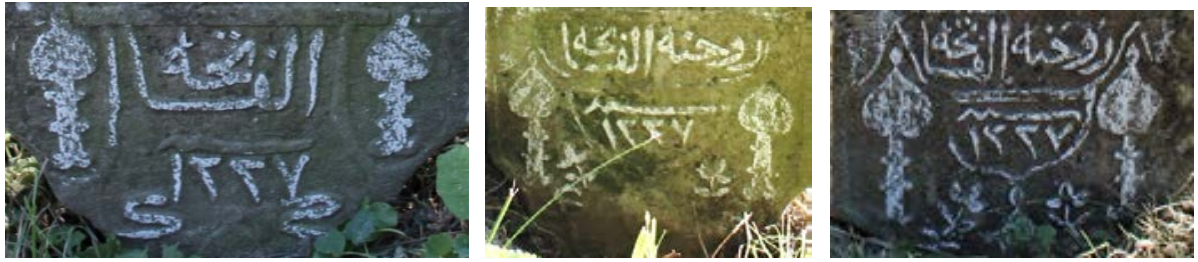

Şekil 12. Sakarya Sapanca'da Tespit Edilen Yeniçeri Remizli 3 Mezar Taşı ve Detayı
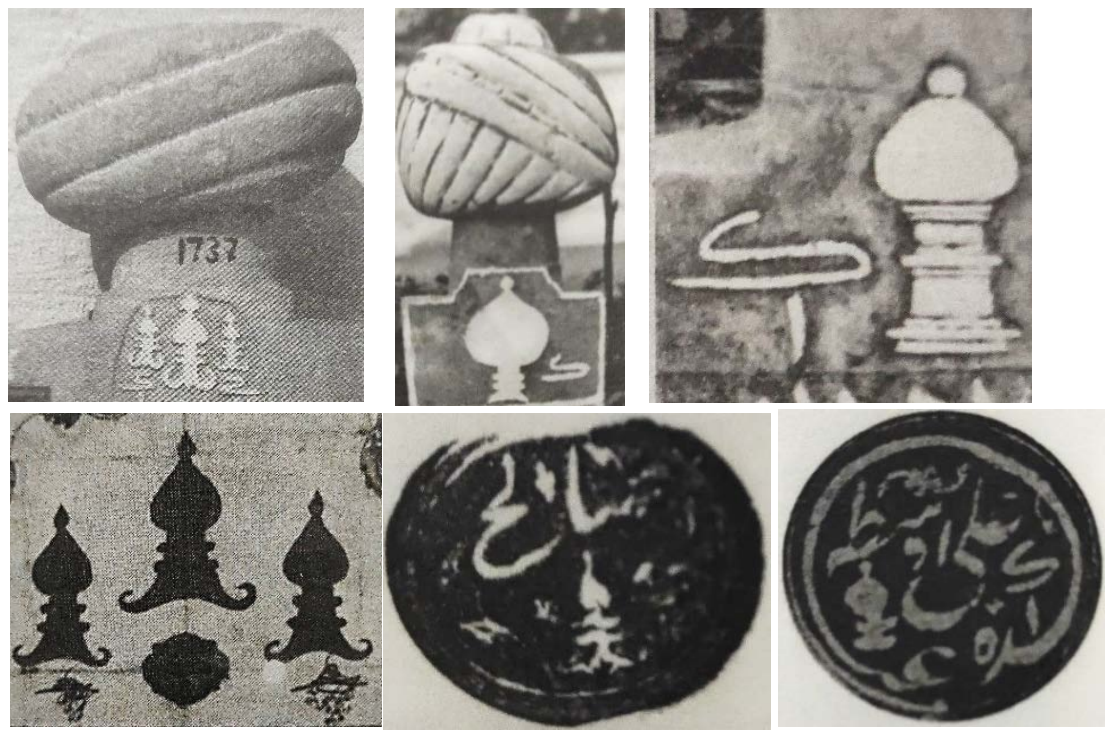

Şekil 13. Yeniçeri 1. Bölük Remizleri, Mezar Taşı, Belge ve Mühürlerde (N. İşi-M. Kökrek, 2017; 222, 223, 290, 158, 220).

Sahada tespit edilen bu üç örneğin remizleri, bu konuda daha evvel yapılmış olan çeşitli yayınlarda da görülmektedir. Sonuçta, Sakarya'daki bu üç mezar taşının, 1. bölük remzi taşımaları nedeniyle, yeniçeri teşkilatı mensuplarına ait oldukları anlaşılmaktadır.


Şekil 14. 1719, 1750, 1758, 1761, 1762. 




Şekil 15. 1763, 1763, 1765, 1768, 1769.
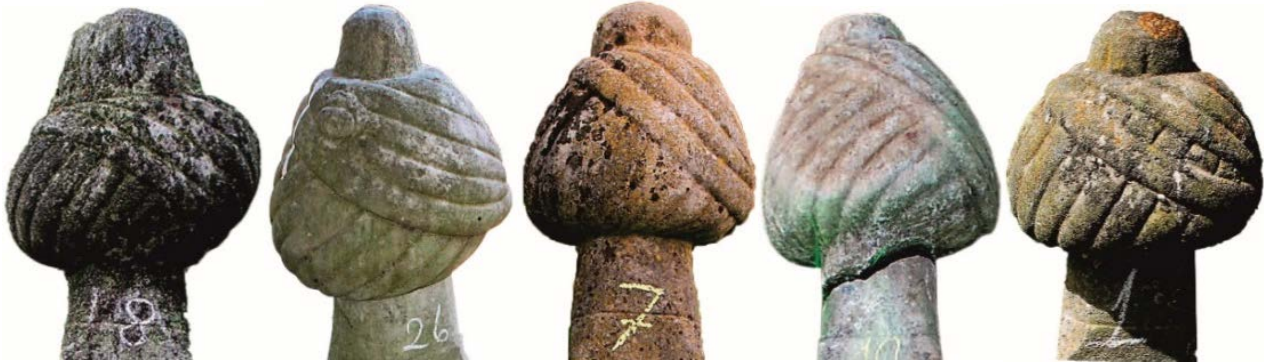

Şekil 16. 1769, 1771, 1772, 1772, 1776.


Şekil 17. 1776, 1776, 1777, 1779, 1779.
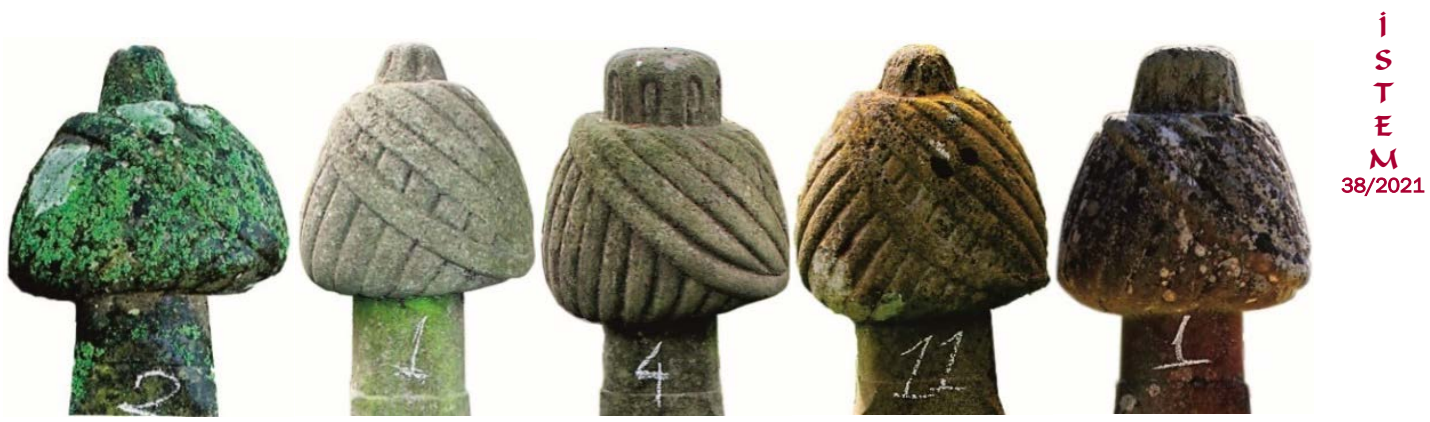

Şekil 18. 1779, 1779, 1780, 1783, 1785. 

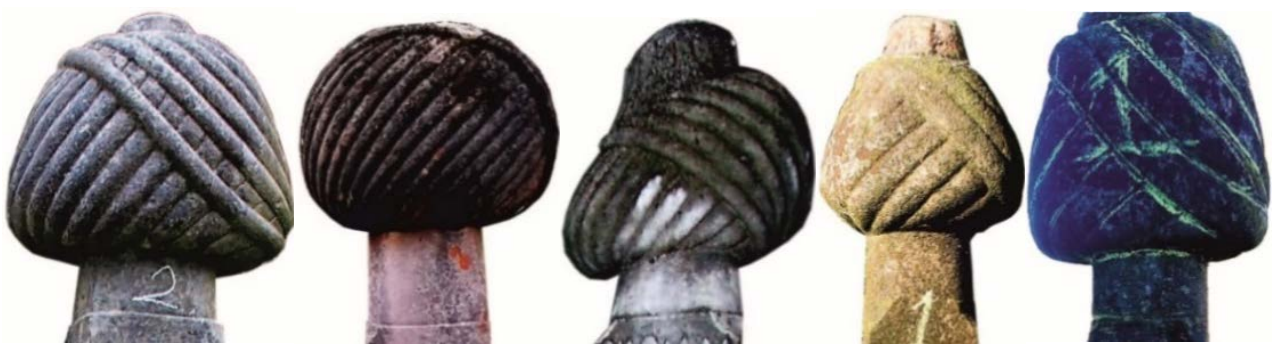

Şekil 19. 1787, 1788, 1794, 1796, 1797.
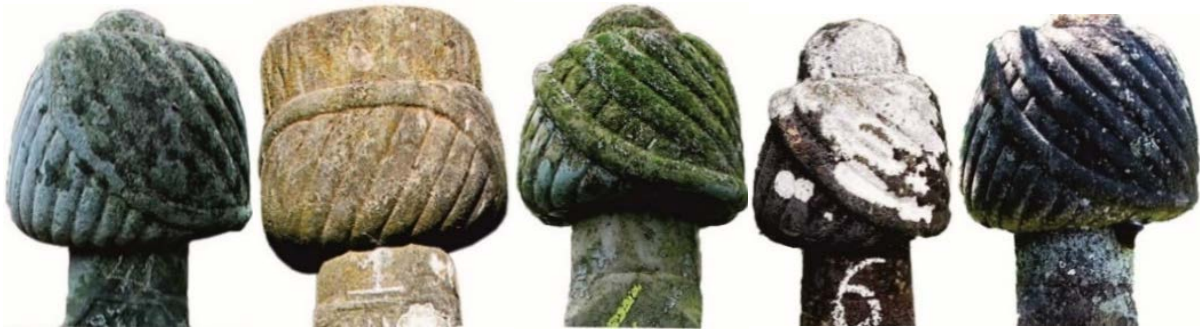

Şekil 20. 1798, 1798, 1800, 1801, 1801.
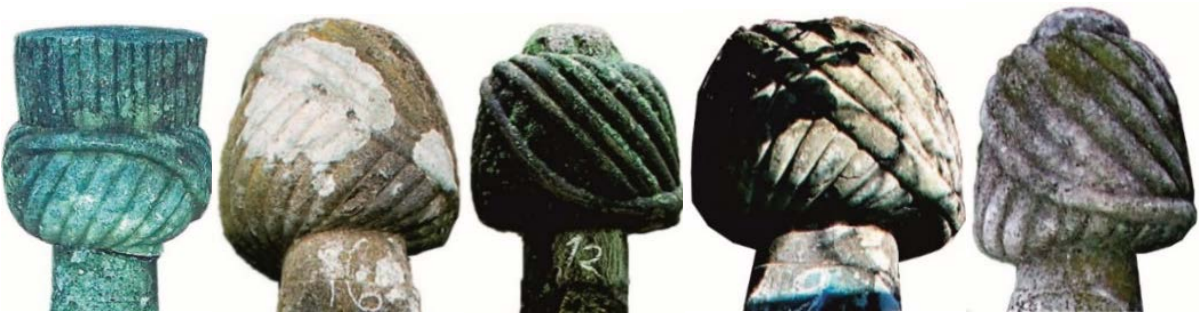

Şekil 21. 1801, 1801, 1802, 1802, 1802.
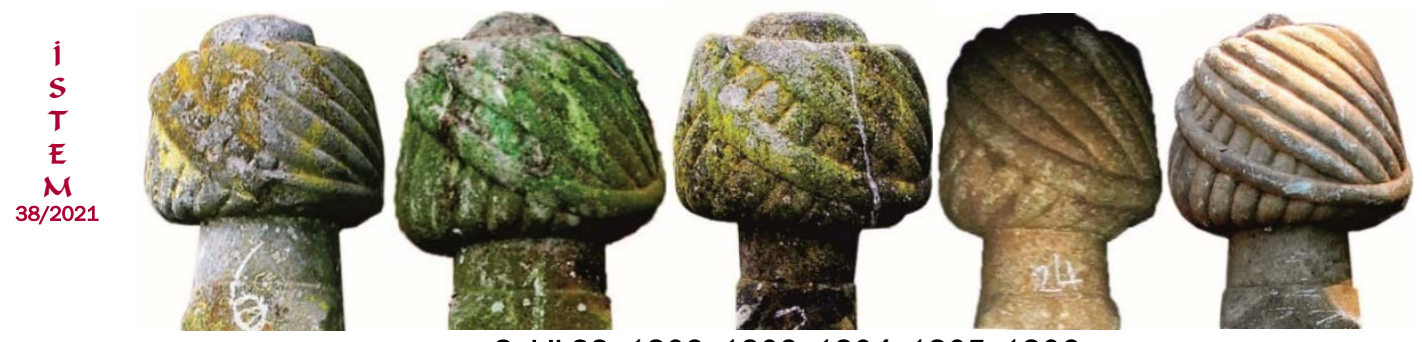

Şekil 22. 1803, 1803, 1804, 1805, 1806.


Şekil 23. 1806, 1807, 1807, 1807, 1808. 



Şekil 24. 1808, 1812, 1812, 1812, 1813.
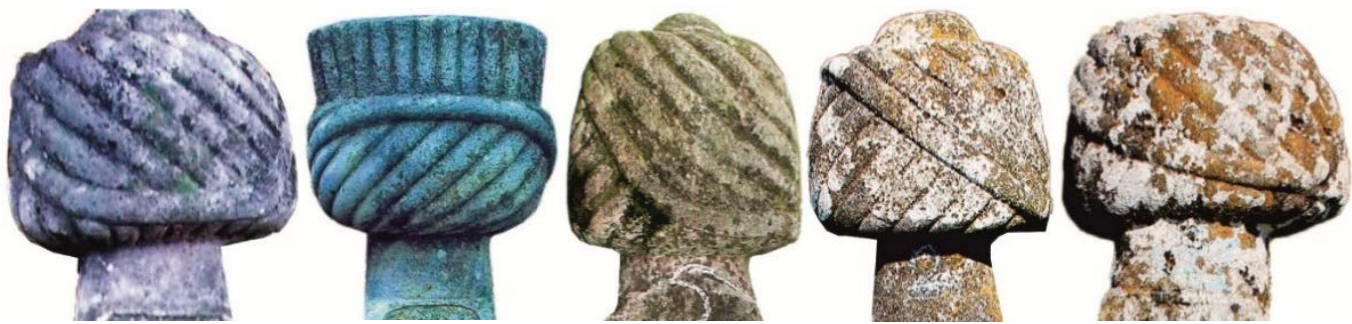

Şekil 25. 1814, 1814, 1815, 1815, 1816.
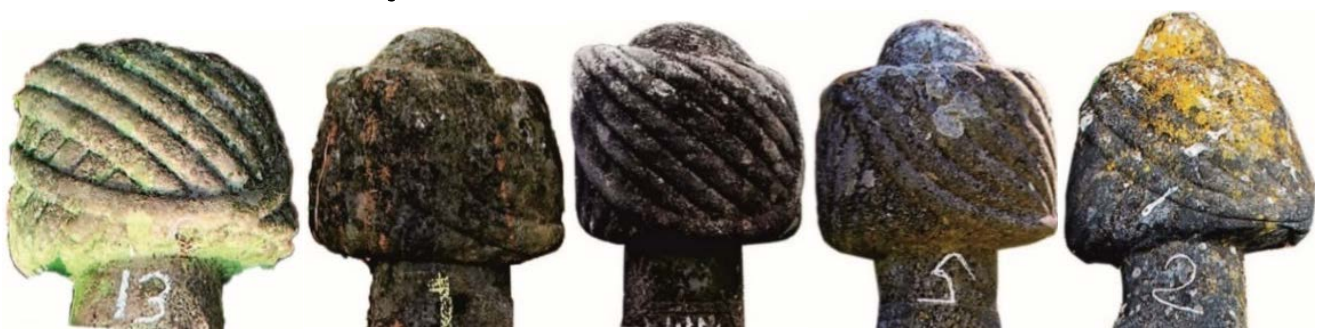

Şekil 26. 1817, 1817, 1819, 1821, 1822.
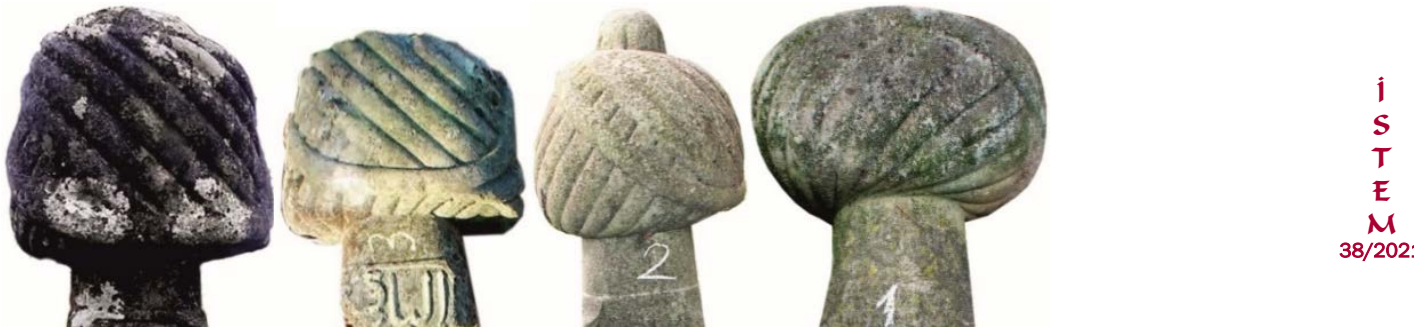

Şekil 27. 1822, 1824, Yok, Yok.

\section{SONUÇ}

Bazı araştırmacılar tarafından dönem anlayışı ve bazıları tarafından da bir sanat olarak yorumlanan kültür varlıklarımız, Türk medeniyetinin sürekliliğini sağlayan toplum hâfızasının bizâtihi kendisini oluşturmaktadırlar. Osmanlı-Türk defin ve mezar gelenekleri de bu hâfıza kayıtlarının okunmasına yardımcı olan unsurlardan birisidir. Toplumsal tarihin başta gelen ana kaynaklarından birisi durumundaki şâhideler, üzerinde taşıdıkları nitelikli izler sayesinde, hem toplumda hâkim olan yaşam şekillerini hem de toplumun kültürel kodlarını ve ge- 
leneklerini temsil eden nişâneler durumundadırlar. Dolayısıyla bu eserler, konumlanmaları, tezyinatları, biçimsel düzenlemeleri ve sembolik temsilleriyle toplumsal kültürün etkili ifade araçları olarak görülmelidirler.

Sakarya mezar taşlarını serpûşların nitelikleri açısından ele alan bu çalışmada, tespit edilen serpûşların yansıttıkları ifadeler hem sanat hem de kültürel bellek yönünden irdelenmiştir. Börk, kalpak, papah, külah, kavuk, sarık, emmame (amâme) ve serpuş gibi birçok dilden gelen kelime ile anılan serpûş kavramı, ilk bakışta karmaşık bir yapı arz etmektedir. Nitekim bu karmaşa akademik araştırmalara da sirayet etmiştir. Bugün tipolojik tanımlama barındıran çaIışmalar, şâhidelerin niteliklerini analiz ederek başlığının ne olduğunu söylemek yerine, üzerindeki sarığın kaç kez sarıldığına, ortasından keçenin çıkıp çıkmamasına, biraz eğik veya biraz dik olup olmamasına bakılarak incelenmiş ve de olanı daha güzel sunma yarışının ürününe dönüşmüş görünmektedir. Bu noktada ortaya çıkan sorunun çözümüne yönelik önerebileceğimiz çözüm ise, incelemelerin konuya bütüncül yaklaşımla yapılmasıdır. Ayrıca birbirine benzer tiplerin aynı çatı altında toplanmasının da faydalı olacağını düşünmekteyiz.

Serpûşların bu denli çeşitlenmesi konusu da en az serpûş terimi kadar karmaşık bir görüntü yaratmaktadır. Son çalışmalardaki ortak anlatım, mezar taşı geleneğinin belirteci olarak dini yaklaşımları öne çıkarmaktadır. Müslüman toplumlarda ve hassaten Osmanlı Türk toplumunda, İslam'ın Hz. Muhammed'in sünnetine bağlılıkla yaşanması geleneği hâkimdir. Elbette bu gelenek mezar taşı serpûşlarının şekillerini de etkilemiş olmalıdır. Bunun yanısıra görüşlerin ya da mezhep ve tarikatların çeşitliliği, farklı türde eserlerin oluşmasına da imkân ve ortam sağlamıştır. Nitekim bugün sahada "Mevlevî, Rufâî, Kâdirî, Bektâşî, vb." birçok örneği görülen serpûş türleri, biçimsel düzenlemesine bu geleneksel yaşama şekilleri sayesinde kavuşmuş görünmektedir. Bunun yanında, serpûş seçiminde elbette farklı toplumsal sâikleri de hesaba katmak gerekmektedir. Örneğin, yeniçerilerin ticari hayata girme yasağını deldikleri durumlarda, gayrimeşru durumunun fark edilmesini önlemek maksadıyla şâhide serpûşlarını farklı mesleklere ait bir biçimde yaptırmış olmaları intimalini düşünmek gerekir. 


\section{Sakarya İlçelerinde Dardağan Başlık Sayıları}

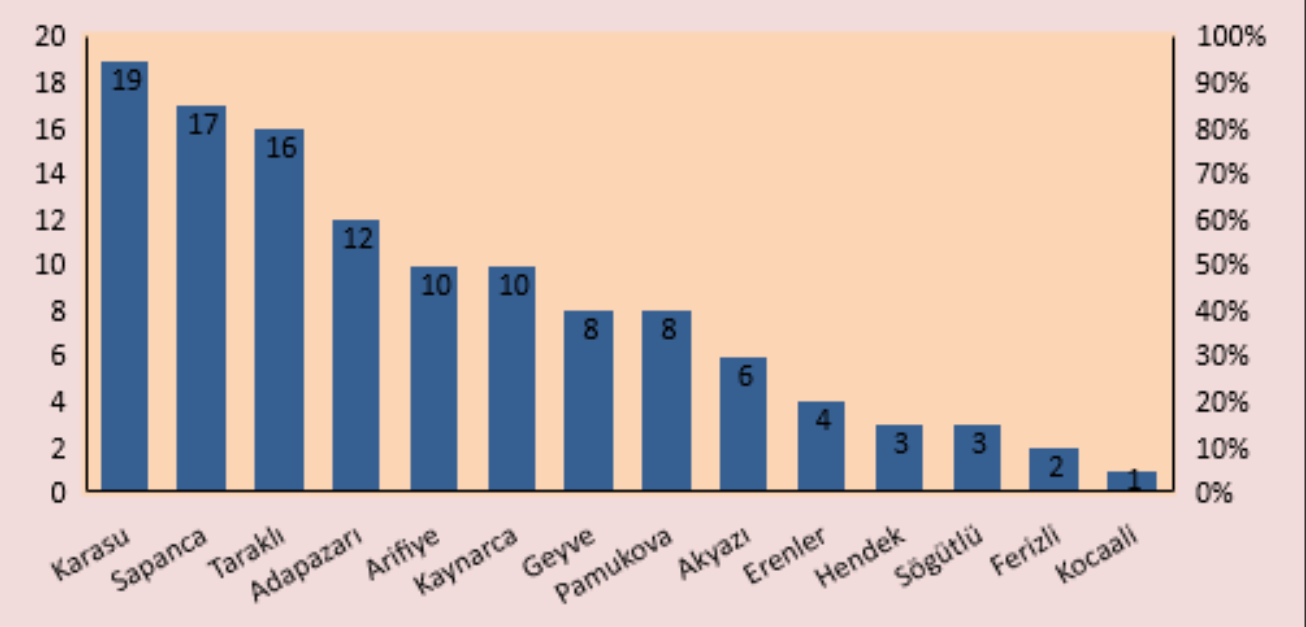

Şekil 28. Sakarya İlçelerinde Dardağan Serpûş Sayıları

Şâhide serpûşlarındaki nitelikleriyle Sakarya mezar taşları, ilgili literatürde önemli bir alanı besleyecek yeterliktedir. Sakarya ilinin merkezi ve ilçelerindeki tüm mezarlıklarda yaptığımız alan çalışması sonucu elde ettiğimiz veriler, tespit edilen toplam 1210 adet şâhideden elde edilmiştir. Bu mezar taşları arasında 119 örnek, serpûşlarıyla incelemeye alınarak literatüre sunulmuştur. 47 mezarIık alanında belirlenen bu şâhidelerin, özellikle dardağan serpûşları ve kitâbeleri üzerinde durulmuştur.

Dardağan serpûş kavramının ilk ne zaman ortaya çıktığı veya etimolojik kökeni üzerine kapsamlı bir araştırma henüz yapılmamıştır. Bunun nedeni, büyük ölçüde verilerin bütünüyle çözülememesi ya da netleşmemesi olmalıdır. Literatürde genel kabulün dardağan olarak kavramlaşması, bizi de kavramı bu çalışmada kullanmaya sevk etmiştir. Fakat çalışmamız sonunda biz de bu konuda bir kesinliğe ulaşamadığımızdan, dardağan başlığın benzerleri veya türevlerini kendi içinde bölmeden bir bütün halinde vermiş bulunmaktayız. Çünkü dardağan başlığın yeniçeri serpûşlarından birisi olarak tanıtılmasıyla birlikte, kendi içinde alt-türlere ayrılması incelemeleri ve tipolojileri zorlaştırmaktadır. Ancak, yine de birbirine oldukça benzeyen bu türlerin temel olarak dardağan türünden gelmiş olmaları, onların bu serpûş altında toplanabileceğinin göstergesi sayılmalıdır.

İleri bir tahmin ve umut olarak söyleyebiliriz ki, ülke genelinde dardağan serpûşlu mezar taşlarının tüm türevleri derlenip toparlandıktan ve bunların bilimsel incelemesi yapıldıktan sonra, hem konunun incelenmesi hem de anlaşılması daha kolay olacaktır. Çünkü hangi başığın doğrudan yeniçeriye ait olduğunu söylemek, sadece serpûş özelinden ele alındığında eksik kalmaktadır. Bugün ulema sarıkı bir şâhidenin kitâbesinde yeniçeri alametleri bulunuyorsa ve tüm dardağan serpûşlar aynı netlikte bir yeniçeri bilgisi veya işareti taşımı- 
yorsa, bu durumda tanım, tasnif ve yorum yaparken genel ifadelerden kaçınmak en doğru yol olmalıdır.

Ayrıca bilinmelidir ki, yeniçeri sınıfına mensubiyetleri nedeniyle beşe unvanına sahip olan bir zümrenin, yeniçeriliğin ortadan kaldııımasıyla bazen saygınlık olarak kullanılıyor olması gibi belli belirsiz nitelendirmelerin tümü, yeniçeri tanımlaması yapma hususunda yanıltıcı olabilecektir. Bu nedenle dardağan serpûş konusunda burada bizim yapmaya çalıştığımız şey, daha çok kitâbelerin içeriklerine göre serpûşların gruplandırılması olarak görülmelidir.

Sakarya sınırlarındaki 119 şâhide "Beşe Unvanlı Mezar Taşlarında Dardağan Serpûşlar, Serdengeçti Unvanlı Mezar Taşlarında Dardağan Serpûşlar, Kitâbelerinde Meslek Belirten Dardağan Serpûşlar, Kitâbelerinde Meslek Belirtilmeyen Dardağan Serpûşlar" olarak 4 serpûş altında incelenmiştir. Bu gruplama yöntemi sayesinde yeniçeri kimliğine sahip olup dardağan serpûş kullananlar ile sahip olmayanları ayırmak daha tutarlı sonuçlara ulaşmayı mümkün kılmaktadır. Bunların yanısıra, başlı̆̆ı veya kitâbesinde yeniçeri ibaresi bulunmadığı halde, yeniçeri remizli şâhideler bulunmaktadır ki, Sakarya'da 1812 tarihli 1. Bölük remzi bulunan mezar taşı buna örnektir.

Sakarya sınırlarında belirlenen dardağan serpûşlu mezar taşlarının kullanım sıklığı ve oranlarına gelince, 1719-1799 yılları arasında toplamda 65 mezar taşı, 1800-1822 yılları arasında 48 mezar taşı ve üzerinde tarih bulunmayan veya kırık olan 6 mezar taşıla, üzerinde dardağan serpûş bulunan şâhide sayısı toplam 119 olarak tespit edilmiştir.

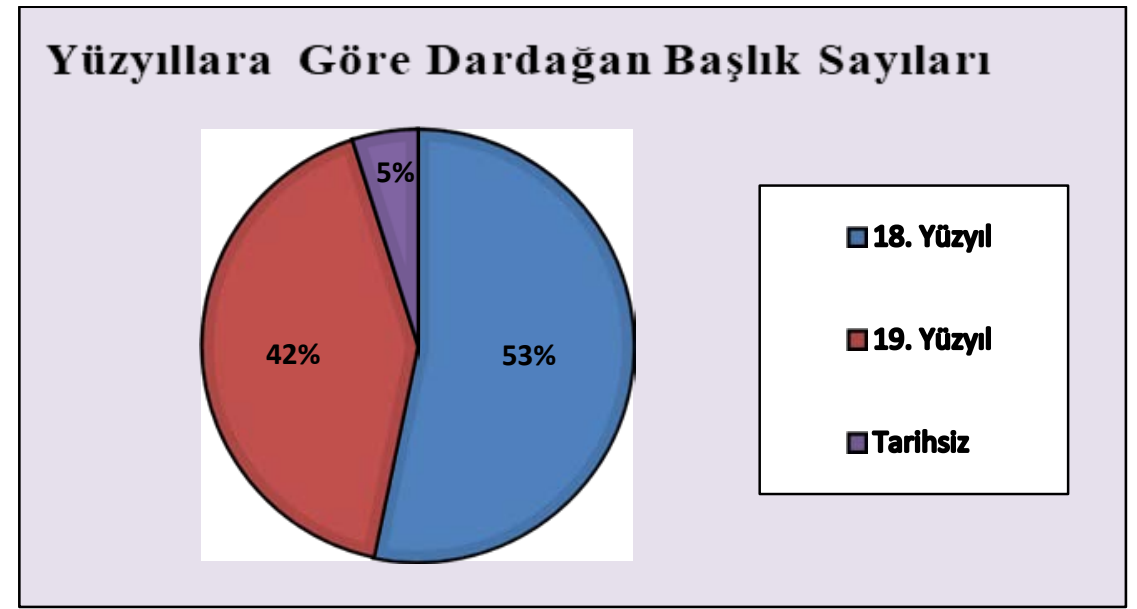

Şekil 29. Sakarya Mezar Taşlarında Dardağan Serpûşların Yüzyıllara göre Dağılımı 


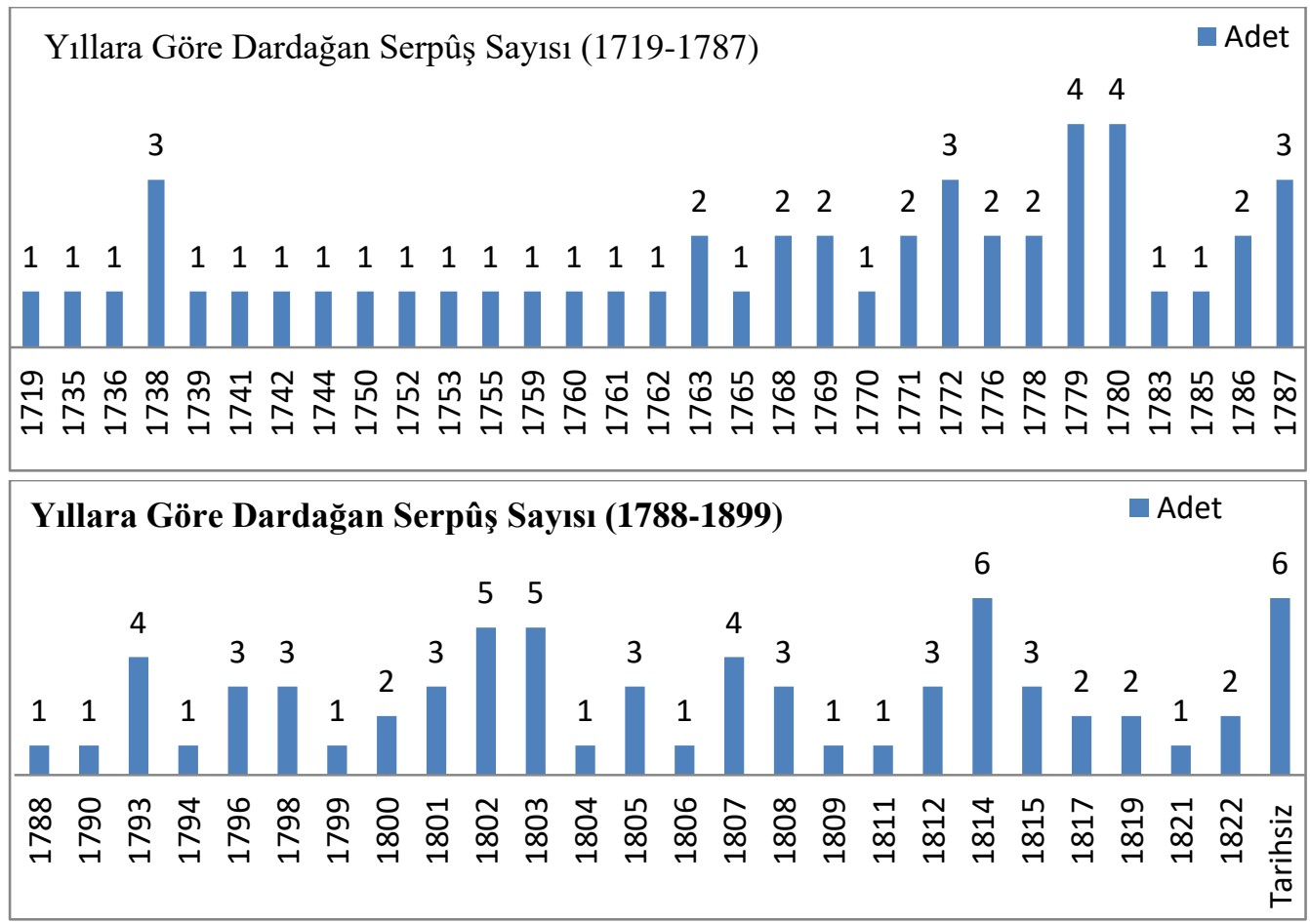

Şekil 30. Sakarya Mezar Taşlarında Tarihlere Göre Dardan Serpûş Analizi

14 ilçede mevcut 47 mezarlık alanda belirlenen 119 şâhidenin tamamı erkek metfunlara aittir. Bunların baş taşları üzerinde dardağan serpûş bulunmaktadır. Bu tür serpûşların kullanıldığı şâhideler dört grup altında ele alınmıştır. Bunlar kitâbelerinde beşe unvanı bulunanlar (40 adet), serdengeçti unvanı bulunanlar (3 adet), meslek yazanlar ve yazmayanlar (79 adet) olarak sınıflandırılmıştır. 119 şâhidenin kitâbesi üzerinde celî sülüs, 3 şâhidenin kitâbesi üzerinde celî ta'lik hattın kullanıldığı belirlenmiştir. 71 şâhide üzerinde teslim ifadesi bulunmazken, diğerlerinde "merhûm ve mağfur (17 adet), el-Bâkî (5 adet), Hüve'l-Bâkî (22 adet), Hüve'l-Hayyü'l-Bâkî (3 adet), Hüve'l-Hallâku'l-Bâkî (3 adet), Hüve'l-Hallâk (1 adet)" şeklinde yazılmıştır. Kitâbelerin verdiği bilgiye göre Karaağaç'lı, Hendek'li, Gülviran'lı, Kayseri'li, Zara'Iı, Kocaeli'li ve Kaymas'lı olarak belirtilen toplamda 7 yer ismi bulunmaktadır.

Tezyin açısından incelendiğinde hiçbir mezar taşında bitkisel veya geometrik süsleme bulunmamaktadır. Fakat toplamda 7 mezar taşında metfun kişilerin yeniçeri teşkilatına mensup olduğu belirlenmiştir. Bunlardan 3 tanesi üzerinde 1. Bölük remzi bulunurken, diğerlerinin kitâbelerinde bölük isimleri yazılı olarak tespit edilmiştir. Sakarya mezar taşı kitâbelerinde metin içinde belirtilen bölüklerin remizlerine dair bilgileri, alan üzerine çalışan araştırmacıların yayınlarından belirlemeye çalıştık. 32, 44, 49, 56 ve 58. Bölük remizlerinin mezar taşlarına hakkedilmiş şekilleri aşağıda verilmiştir. 

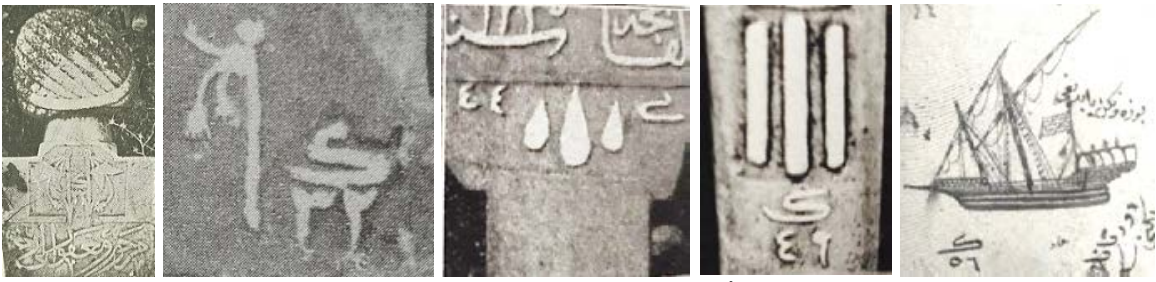

Şekil 31. 32, 44, 49, 56 Bölük Remizleri (N. İşli-M. Kökrek, 2017; 298, 299, 211; E. Ferit Koyaş, 1978; 53; M. Kökrek, 2015; 62).

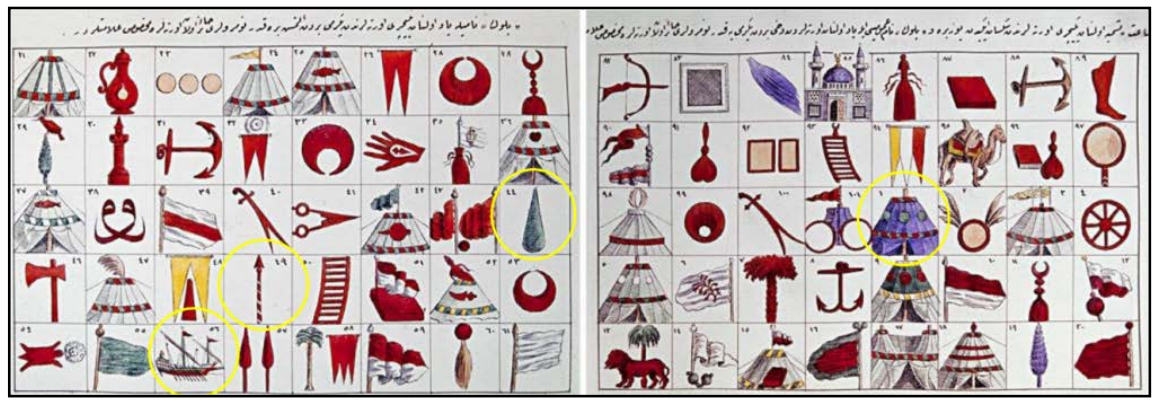

Şekil 32. Yeniçeri Remizleri (M. Ş. Paşa, 1326; 108-109; DiA, 1992; 324).

Burada dikkat çekmek istediğimiz husus, yeniçeri mezar taşlarında çok etmenli ya da çoğulcu sorgulama tekniklerinin kullanılması gerekliliğidir. Çünkü yalnızca serpûş ve biçimsel özellikler üzerinden sonuçlara gidildiğinde, yönteminde bir takım eksikler oluşacaktır.

Bu çalışma sayesinde ortaya çıkan belki de en kesin sonuç, Sakarya sınırlarında bulunan Osmanlı devri mezar taşlarının, acilen onarım ve koruma çaIışmalarına konu edilmesi zorunluluğudur. Bu mezar taşlarında çözümleme ve okumaların tamamlanması sayesinde, bölgedeki zengin Türk kültürünün izleri ortaya çıkarılmış ve bunlar araştırmacıların hizmetine sunulmuştur. Genel temizleme ve onarım çalışmalarının ardından, daha nice bilimsel tespit ve sonuçlar bu mezar taşları üzerinden şehre ve ülkeye kazandırılmış olacaktır.

Author Contributions / Yazarların Katkısı: This article is a work with twoauthors. The contribution of the aforementioned authors to the preparation of the article is equal. / Bu makale, iki yazarlı bir eserdir. Makalenin hazırlanmasına söz konusu yazarların katkısı eşittir.

Funding / Finansman: This research received no external funding. / Bu araştırma herhangi bir dış fon almamıştır.

Conflicts of Interest / Çıkar Çatışması: The author declare no conflict of interest. / Yazar, herhangi bir çıkar çatışması olmadığını beyan eder.

\section{Kaynaklar}

» Acar, Şinasi - Özveri, Murat. “Yaycı Yusuf Beşe Terekesinin Düşündürdükleri”, Osmanlı Bilimi Araştırmaları 9, (2008): 120, 122.

» Açık, Turan. “Beşe Unvanı Hakkında”, Tarih Dergisi 62/2, (2016): 37-64.

" Akbel, Mustafa. "Tereke Kayıtlarından Hareketle Yeniçerilerin Sosyo-Ekonomik Durumları", Tarihin Peşinde-Uluslararası Tarih ve Sosyal Araştırmalar Dergisi 15, (2016): 264.

» Atıl, Arzu Çakıl. "Rölyef Heykel”, Yedi: Sanat, Tasarım ve Bilim Dergisi 14 (2015): 1-10. 
» Ayanoğlu, Fazıl İsmail. “Vakıflar İdaresince Tamir Ettirilen Tarihi Makberler”, Vakıflar Dergisi 2, (1942): 399.

" Berk, Süleyman. “Osmanlı Mezar Taşı Kitâbelerinde Serpûşlar ve Anlamları”, 1. Uluslararası Türk-Isslam Mezar Taşları Kongresi Bildiriler Kitabı, Aydın: Yeni Fikir Dergisi Yayınları, (2018): 118.

" Berk, Süleyman. Zeytin Burnu'nun Tarihi Mezar Taşları - Zamanı Aşan Taşlar, İstanbul: Zeytin Burnu Belediyesi Yayınları, 2006.

» Beydilli, Kemal. “Yeniçeri”, TDV İslâm Ansiklopedisi 43, İstanbul, (2013): 461.

" Bozkurt, Nebi. “Sarık”, TDV İslâm Ansiklopedisi 36, 2009, (İstanbul): 152.

" Caferoğlu, Ahmet. "Türk Onomastiğinde "Serpûş” yahut "Serpuş”, VIII: Türk Dil Kurultayında Okunan Bilimsel Bildiriler, Ankara: TTK Yayınları, 1960: 116

» Çal, Halit - Canyurt, Filiz. “Edirne Şehrindeki Mezar Taşlarında Serpûş Tipleri”, TURKMES 2019 Tam Metin Bildiriler, Kayseri: Kimlik Yayınları, (2020): 238.

» Çal, Halit. “Karadeniz Bölgesinde 18. Yüzyıl Erkek Mezar Taşları”, Türk Kültürü ve Hacı Bektaş Veli Araştırma Dergisi 87, (2018): 115,118,121.

" Çal, Halit. “Türklerde Mezar - Ankara Mezar Taşları”, Aile Yazıları 8, Ankara: T.C. Aile ve Sosyal Politikalar Bakanlığı Yayınları, (2015): 311.

» Çal, Halit. Boyabat Mezar Taşları, Boyabat Belediyesi Kültür Yayınları, 2015.

" Çetintaş, M. Burak. “istanbul Mezarlıklarındaki ve Hazirelerindeki Yeniçeri Mezar Taşları ile Yeniçeri Mezar Taşlarının Bazı Hususiyetleri”, Imparatorluk Başkentinden Kültür Başkentine, İstanbul: Kitâbevi Yayınları, 2010: 231.

» Çoruhlu, Tülin - Alkan, Murat. "Sakarya/Kocaali İıçesi Osmanlı Dönemi Mezarlıkları Ve Mezar Taşları”, Geleneksel Türk Mezar Taşları I. Ulusal Sempozyumu, Aydın: Erciyes Üniversitesi Yayınları, (2017): 561.

» Edecin, Nilüfer. Sakarya'da Nüfus Hareketleri, Yüksek Lisans Tezi: Sakarya Üniversitesi, 2007.

" Ekim, Zeynep Emel. “Üsküdar ve Yeniçeri Remizle”, Uluslararası Üsküdar Sempozyumu VII, İstanbul: Üsküdar Belediyesi Yayınları, (2012): 701,708.

" Eldem, Edhem. "Yeniçeri Mezartaşları Kitabı Vesilesiyle Yeniçeri Taşları ve Tarih Üzerine" Toplumsal Tarih Dergisi 188, (2009): 10.

" Erkan, Nevzat. "Osmanlı İstanbul'unda Cenaze ve Defin İşlemleri: H.1117/M.1705 Tarihli Sicil Kaydına Göre”, Rumeli İslâm Araştırmaları Dergisi 4, (2019): 58.

" Gündoğdu, Hamza - Yılmaz, Zeki. “Çorlu'da Fatih Camii ve Haziresindeki Mezar Taşları”, Geleneksel Türk Mezar Taşları I. Ulusal Sempozyumu (24-26 Mart 2017), Kayseri: Erciyes Üniversitesi Yayınları, (2017), 168-169.

» Haseki, Mehmet "Plastik Açıdan Türk Mezar Taşları", İstanbul Devlet Güzel Sanatlar Akademisi, (1976):, 13-4.

» İşli, H. Necdet - Kökrek, Mehmet. Yeniçeriler Remizleri ve Mezar Taşları, İstanbul: Dergâh Yayınları, 2017.

» İşli, H. Necdet. Osmanlı Serpuşları, İstanbul: 2010 İstanbul Kültür Başkenti Ajansı Yayınları, 2009.

» İşli, H. Necdet. Yeniçeri Mezartaşları, İstanbul: Turkuaz Yayınları, 2006.

» Karamağaralı, Beyhan. Türk Mimari Eserlerinde Ahlat Mezar Taşları. Ankara: Elektronik Iletişim Ajansı Yayınları, 1993.

» Kaya, Miyase Koyuncu. "Esnaf Loncalarında Yeniçeriler”, History Studies 5/4, (2013): 189.

" Koyaş, Erdoğan Ferit. "Yeniçerilerin Orta ve Bölük İşaretlerinin Sembolik Anlamları", Tarih ve Edebiyat Mecmuası 10, (1978): 54.

» Kökrek, Mehmet. “Edirne'deki Yeniçeri Şâhideleri”, Türk Dünyası Tarih Kültür Dergisi, (2015): 31-32.

" Kökrek, Mehmet. “Yeniçeri Damgaları”, Siyah Sanat Kültür Sanat Dergisi 5-6, (2015): 58, 62.

" Kökrek, Mehmet. Osmanlı Serpuşları, iSMEK El Sanatları Dergisi 20, (2015): 50.

» Kumbaracılar, İzzet. Serpuşlar, İstanbul: Türkiye Turing ve Otomobiller Kurumu Yayını, 1979.

" Laqueur, Hans Peter. Hüve'l Baki Istanbul'da Osmanlı Mezarlıkları ve Mezar Taşları, (çev.) Selahattin Doludizgin, İstanbul: Tarih Vakfı Yurt Yayınları, 1997.

» Özcan, Abdulkadir. "Bölük", TDV İslâm Ansiklopedisi 6, İstanbul: Türkiye Diyanet Vakfı Yayınları, (1992), 324-325.

» Özcan, Ali Rıza. İstanbul'un 100 Mezar Taşı. İstanbul: IBBB Kültür A.Ş. Yayınları, 2012.

» Pakalın, Mehmet Zeki. Osmanlı Tarih Deyimleri ve Terimleri Sözlüğü 1, İstanbul: MEB Yayın- 
ları, 1993.

» Pakalın, Mehmet Zeki. Osmanlı Tarih Deyimleri ve Terimleri Sözlüğü 3, İstanbul: MEB Yayınları, 1993.

" Paşa, Mahmut Şevket. Osmanlı Teşkilât ve Kıyafet-i Askeriyesi, İstanbul: Mekteb-i Harbiye Matbaası, 1326.

" Şenyurt, Oya. "On sekizinci Yüzyıl Osmanlı Başkentinde Taşçı Örgütlenmesi”, METU JFA 26:2, (2009): 110, 117.

» Şeyban, Lütfi - Gündogdu, Oktay. “Sakarya Mezar Taşlarının Tarihi Dizin ve Dönem Analizleri”. Akademik incelemeler Dergisi 15/2, (2020): 3-13.

" Şeyban, Lütfi - Kır, Oguzhan. Osmanlı Mimari ve Mezar Taşı Kitâbeleriyle Sakarya 16391946, Sakarya: Sakarya Büyükşehir Belediyesi Kültür ve Sosyal İşler Daire Başkanlığı Yayınları 2019.

" Yalçın, İsmail “Sarık”, TDV İslâm Ansiklopedisi 36, İstanbul, (2009): 154.

"Yavuz, Sena. Sakarya Illi Geyve İlçesi Osmanlı Dönemi Mezar Taşları, Yüksek Lisans Tezi: Sakarya Üniversitesi, 2013.

» Yücel, Yaşar. Osmanlı Devlet Teşkilatına Dair Kaynaklar, Ankara: TTK Yayınları, 1988. 